\title{
On the Legal Status of the Proposition that "Life Begins at Conception"
}

\author{
Jed Rubenfeld*
}

For eighteen years, a majority of the Supreme Court has upheld abortion rights without deciding whether or when a fetus may be regarded as an independent person. Today, another set of Justices would deny those rights on the ground that the fetus's status is an issue for state legislators to resolve. These mirror-image strategies share a common aim: Each allows the Court to evade the single question that, in every discourse but the judicial one, is by now synonymous with the abortion debate itself-the question of when human life begins. ${ }^{1}$

The policy of avoidance began at the outset of the Court's abortion jurisprudence. In Roe v. Wade, the Court expressly refused to "speculate" about "this most sensitive and difficult question." 3 Instead, the Roe Court predicated governmental power to forbid abortion on the putative state interest in "protecting the potentiality of human life." 4 It was this interest in "potentiality" that the Court held to become "compelling" when the fetus reaches viability. 5

Roe's "potential life" holding had distinct advantages. In particular, by sustaining a prohibition of abortion on the basis of the fetus's status as a "potential" person, the Court avoided the necessity of deciding at what point in a woman's pregnancy a state could deem the fetus an actual person. ${ }^{6}$

- Associate Professor, Yale Law School. My thanks to Bruce Ackerman, Akhil Amar, David Kornblau, and Amy Chua for their comments and contributions.

1. A note on terminology: "human life" and "person" are not synonymous terms, and personhood need not logically be defined as an attribute of human life. Thus someone might say that a fetus (or even an infant) is a human being but not a person-not, that is a creature entitled to legal or moral rights, in particular, a right to life. See, eg., Michael Tooley, Abortion and Infanticide, 2 PhIL. \& PUB. AFF. 37, 40 (1972). But I take it that the proposition "life begins at conception," as used in the abortion debate, refers to a concept of human life that includes the essential rights of personhood. To have force in this debate, calling the fetus a human life (or human being) must imply that the fetus has a right to life. See note 97 infra. Because I mean by "person" essentially a creature with a right to life, I shall use the terms "human being," "human life," and "person" interchangeably. In addition, the word "fetus" in this essay refers to the unborn throughout gestation, including the embryonic phase.

2. 410 U.S. 113 (1973).

3. Id. at $159-60$.

4. Id. at 162 (emphasis added).

5. Id. at 163 .

6. Perhaps as a result, the question of the fetus's personhood has also remained underexamined in the volumes of commentary on Roe, where issues of constitutional interpretation have predominated. On the rare occasions when leading scholars-both proponents and opponents of abortion rights--have raised the issue of fetal personhood, they have generally suggested that it is 
The cost of this approach has now become clear. In abortion cases following Roe, dissenting justices began forcefully to challenge the idea that the state's interest in protecting "potential human life" somehow hinged upon the fetus's viability. ${ }^{7}$ In 1989 , a plurality of the Court held in Webster $v$. Reproductive Health Services ${ }^{8}$ that this compelling state interest existed "throughout pregnancy,"9 and it appears that at least four Justices now share this view. ${ }^{10}$ By Roe's own logic, to hold that the state's interest in protecting "potential life" exists equally throughout pregnancy is to hold that states may bar abortion completely. Thus, with the addition of Justice Scalia, who has explicitly called for Roe to be overruled, ${ }^{11}$ there would already be five votes to do away with Roe-if, that is, Roe's own critical premise were accepted. ${ }^{12}$

But that premise, I propose to show, cannot be accepted: Predicating abortion regulations on a putative state interest in preserving "potential human life" is both logically and constitutionally untenable. If the fetus is considered solely as a "potential" person, no case for a compelling state interest can be made without (1) covertly treating this supposed "potentiality" as an actuality and (2) inviting wholly insupportable consequences about the state's power to dictate our reproductive decisions. The "potential life" premise, first employed to undergird Roe and now to undermine it, is and has always been erroneous. Only the fetus's status as an actual person, not a potential person, can provide the compelling state interest necessary to support a prohibition of abortion. ${ }^{13}$

If this is so, however, then the question of judicial competence becomes all the more pressing. What can judges possibly say about life's beginning when religions war and science hold its tongue? Whether ultimately a matter of faith or fact, personhood cannot be a subject fit for judicial resolution.

This conclusion would be unassailable if it were correct to wrap the fetus's personhood in a veil of religious or medical mystery. But this view of personhood is surely misconceived, at least in assessing the validity of abor-

irrelevant to the constitutional outcome. Compare Laurence H. Tribe, Abortion: The Clash OF ABSOLUTES 129-35 (1990) (arguing for abortion rights even assuming fetuses are persons) with John Hart Ely, The Wages of Crying Wolf: A Comment on Roe v. Wade, 82 YALE L.J. 920, 926 (1973) (arguing against abortion rights even assuming fetuses are not persons).

7. See, e.g., Thornburgh v. American College of Obstetricians and Gynecologists, 476 U.S. 747, 795 (1986) (White, J., dissenting) ("[T] he State's interest, if compelling after viability, is equally compelling before viability."); id. at 828 (O'Connor, J., dissenting) (asserting that state's interests in ensuring maternal health and protecting potential life exist throughout pregnancy); Akron v. Akron Center for Reproductive Health, 462 U.S. 416, 460-61 (1983) (O'Connor, J., dissenting) ("[P]otential life is no less potential in the first weeks of pregnancy than it is at viability or afterward.").

8. 109 S. Ct. 3040 (1989).

9. Id. at 3057 (plurality opinion).

10. Chief Justice Rehnquist and Justices White and Kennedy formed the Webster plurality, and Justice O'Connor had already taken this position in prior cases. See note 7 supra. infra.

11. See, e.g., Webster, 109 S. Ct. at 3064-65 (Scalia, J., concurring); text accompanying note 67

12. For this reason, some commentators hailed Webster as spelling the "de facto" end of Roe. See, e.g., James Bopp, Jr. \& Richard E. Coleson, What Does Webster Mean?, 138 U. PA. L. REV. 157 (1989).

13. See Part II infra. 
tion laws. Religious tenets can play no part in a state's determination of fetal personhood, for obvious constitutional reasons. And personhood is not a matter of fact. It is not a thing or a concrete property inhering in a thing. It is a status, legal and moral, that we confer as a normative matter at a certain point in human development. Stripped of any reifying (or theifying) premises, personhood is no different in its conceptual structure from another status conferred later in life: adulthood. ${ }^{14}$

What follows from this? First, as with adulthood, there need be no unique or absolute legal answer to the "question of personhood." This not only means that different legislatures may answer the question differently; it means that different answers may be appropriate in different contexts-abortion, inheritance, assault, and so forth-depending on the particular legal or moral considerations at issue.

Second, again as with adulthood, there may nonetheless be limits on a state's discretion in determining the advent of personhood-limits imposed by the concept itself, if it is to retain any normative meaning, as well as limits imposed by the Constitution. ${ }^{15}$ Just as it would be absurd and likely unconstitutional for a state to deem adulthood to begin at age two or sixty, so too there may be limits on a state's discretion to decide when personhood begins.

Finally, the consequences of deeming a fetus a person must be recognized as relevant to the decision of when (if ever) a fetus acquires this status. When states establish the age of fifteen as the advent of adulthood for the purposes of criminal liability or twenty-one for drinking, they take into account not only matters of biological development, but also the interests of other parties. So too, in determining the advent of personhood, it is appropriate for states to treat the effects that this status will have on others as a consideration within the determination itself.

Indeed, in the specific context of abortion law, consideration of the consequences is more than appropriate; it is constitutionally required. Because it establishes the point at which a woman's constitutional right may be abridged, the determination of a fetus's personhood cannot be divorced from the constitutional interests protected by that right. To conduct this inquiry without taking into account those constitutional interests would be like trying to discern the nature of a "clear and present danger" while excluding any reference to the principles and purposes of the first amendment. If these premises are accepted, I shall argue, then the proposition that "life begins at conception" must, for constitutional purposes, be rejected. ${ }^{16}$

Part I of this article sets forth the applicable doctrinal framework, with particular focus on Roe and Webster. Part II critically examines the proposition that the preservation of "potential human life" is a compelling state interest capable of supporting the proscription of abortion. Part III takes up

14. See Part III.A, B infra.

15. See Part III.C infra.

16. See Part III.D infra. 
the issue of fetal personhood. Unless the right to privacy is abolished, the Court has no choice but to address this issue and, I shall try to show, no choice but to resolve it so as to prevent states from blocking abortion altogether.

\section{Doctrinal FramewORK}

For purposes of this article, we shall assume that the constitutional right of privacy has not been repudiated. ${ }^{17}$ More specifically, we shall assume that in considering Roe, the Court will remain bound by the contraception cases, notably Griswold ${ }^{18}$ and Eisenstadt. ${ }^{19}$ The Webster plurality expressly stated that it was not calling these cases into question, ${ }^{20}$ and no serious challenge to them currently appears tenable. ${ }^{21}$ So long as these cases stand, our constitutional law recognizes a right not to have the state dictate one's "decision whether to bear or beget a child."22 Prohibiting abortion would plainly contravene this right and hence would be permissible only if necessary to further a "compelling state interest." 23 Given this doctrinal framework, the relevant question, as formulated in both Roe and Webster, is whether the state has a "compelling" interest in the preservation of a fetus. ${ }^{24}$

To be sure, we are presupposing that abortion concerns the "decision whether to bear or beget a child" just as contraception does, so that the "liberty interest" involved in both actions is of the same constitutional magnitude. Despite its straightforwardness, this presupposition (which is necessary to our claim that abortion can only be proscribed in order to satisfy a compelling state interest) might conceivably be challenged.

For example, Justice White has argued that the presence of a fetus in the abortion decision alters "the characterization of the liberty interest itself."25

17. If the Court were to renounce the right of privacy altogether, then under current doctrine antiabortion laws would presumably be valid regardless of the fetus's personhood. Cf., e.g., Bowers v. Hardwick, 478 U.S. 186, 196 (1986) (holding that antisodomy laws did not implicate the right of privacy and were therefore valid even if based solely on "majority sentiments" about the "morality" of the proscribed conduct). Should antiabortion laws ever be held to implicate other constitutional guarantees (such as that of equal protection), the question of the fetus's status would again become relevant and the arguments presented herein would still apply.

18. Griswold v. Connecticut, 381 U.S. 479 (1965).

19. Eisenstadt v. Baird, 405 U.S. 438 (1972); see also, e.g., Carey v. Population Servs. Int'l, 431 U.S. 678 (1977).

20. Webster v. Reproductive Health Servs., 109 S. Ct. 3040, 3058 (1989).

21. Justice White concurred in the Court's judgment in both cases, see Eisenstadt, 405 U.S. at 463-64; Griswold, 381 U.S. at 502-03, and Justices O'Connor and Kennedy specifically indicated their support for these cases in Michael H. v. Gerald D., 109 S. Ct. 2333, 2346 (1989) (O'Connor, J., concurring).

22. Eisenstadt, 405 U.S. at 453.

23. See, e.g., Carey, 431 U.S. at 686. The "compelling state interest" test applies to numerous constitutional guarantees quite apart from the right of privacy. See text accompanying notes 31-33 infra; Roe v. Wade, 410 U.S. 113, 155 (1973) (citing cases). To pass this test, a law not only must further a compelling state interest, but must be "narrowly drawn to express only the legitimate state interests at stake." Roe, 410 U.S. at 155.

24. See Webster, 109 S. Ct. at 3057 (plurality opinion); Roe, 410 U.S. at 155, 163.

25. Thornburgh v. American College of Obstetricians and Gynecologists, 476 U.S. 747, 792 n.2 (1986) (White, J., dissenting). 
According to Justice White, abortion laws should "call into play [only] the most minimal judicial scrutiny"; ${ }^{26}$ otherwise the Court would be "interposing a constitutional barrier to state efforts to protect human life and ... investing mothers and doctors with the constitutionally protected right to exterminate it."27

This sort of argument ${ }^{28}$ simply prejudges the decisive issue: whether a fetus constitutes an independent human life from the moment of conception. ${ }^{29}$ If the fetus is regarded as a person, then of course the state has a compelling interest in protecting it. In the absence, however, of any preconceived idea about fetal status, it becomes quite difficult to explain why abortion differs from contraception. Without more, the claim that abortion differs because of the presence of a fetus simply begs the question-the question, that is, of whether the state's interests in the fetus are sufficiently "compelling" to override a constitutionally recognized right. ${ }^{30}$

But what is a "compelling" state interest? Unfortunately, scant jurisprudence exists on this subject. This creates a doctrinal instability not only for the right to privacy, but for all the rights to which the "compelling state interest" test applies-for example, the guarantees of equal protection ${ }^{31}$ and free speech. ${ }^{32}$ In some areas, the criteria necessary to establish a compelling state interest have been more narrowly articulated. ${ }^{33}$ On the whole, however, the compelling state interest doctrine remains an unstructured balanc-

26. Id. at 790 (White, J., dissenting). To say that a law is subject to "strict scrutiny" is to say that the compeling state interest test will be applied. By "the most minimal judicial scrutiny," Justice White is presumably referring to a mere rationality test.

27. Doe v. Bolton, 410 U.S. 179, 222 (1973) (White, J., dissenting).

28. Cf. Michael H. v. Gerald D., 109 S. Ct. 2333, 2343 n.4 (1989) (plurality opinion) (condemning the "strange procedure of looking at the act which is assertedly the subject of a liberty interest in isolation from its effect upon other people").

29. Justices White and Scalia could not rescue their argument by saying that abortion at least destroys the "potential" for human life; the very same could be said of contraception. In any event, all such arguments go to the state interest at issue, not the nature of the liberty interest. See Walter Dellinger \& Gene B. Sperling, Abortion and the Supreme Court: The Retreat from Roe v. Wade, 138 U. PA. L. REV. 83, 94 (1989).

30. But perhaps it will be said that Griswold and Eisenstadt stand for a constitutional liberty interest not in deciding whether and when to have children, but only whether and when to conceive them. In that event, abortion would implicate quite a different liberty interest. Eisenstadt's express language, however, is to the contrary. See Eisenstadt, 405 U.S. at 453 (emphasizing the right to be free from state intrusion into one's "decision whether to bear or beget children") (emphasis added). Moreover, apart from concerns about the police invading a bedroom for evidence (mentioned in Griswold but not implicated or raised in subsequent cases such as Eisenstadt), an interest in control over conception makes little sense in the absence of an interest in control over reproduction. Why protect the decision to conceive except to protect the decision to bear?

Someone might yet protest that the freedom to buy and use contraceptives is itself a constitutionally adequate protection of the reproductive decision or at least so sufficient a protection that a prohibition of abortion need not be supported by a compelling state interest. As to these objections, which do not challenge the existence of the liberty interest as such, see note 134 infra and accompanying text.

31. See, e.g., Austin v. Michigan Chamber of Commerce, 110 S. Ct. 1391, 1397 (1990).

32. See, e.g., Perry Educ. Ass'n v. Perry Local Educators' Ass'n, 460 U.S. 37, 45 (1983).

33. To take a familiar example, the Court long ago held that a state may prohibit speech otherwise insulated by the first amendment if such speech would create a "clear and present danger" of a harm that the state is empowered to avert. See, eg., City of Houston v. Texas, 482 U.S. 451, 461 (1987); Schenck v. United States, 249 U.S. 47, 52 (1919). 
ing test in which our constitutional guarantees may always give way to raisons d'état. This conclusion may be somewhat disconcerting, but the problem belongs to constitutional law as a whole, not the right of privacy in particular.

Although there are no set formulas defining compelling state interests, the case law suggests one observation of particular importance to the abortion question. When someone's conduct invades the protected interests of another individual, the state's burden is far more easily satisfied. First amendment rights, for example, are generally limited by the laws of battery and trespass. I am not permitted to protest a politician's face by rearranging it; nor does my right to demonstrate allow me to march on my neighbor's lawn. ${ }^{34}$ And the compelling state interest test would certainly seem satisfied, as we have already suggested, if my conduct would take another person's life. ${ }^{35}$

This conclusion is of course what makes the fetus's personhood important in the abortion debate. But neither Roe nor Webster rests in any way on a determination that the fetus is or becomes a person at some point in pregnancy. To the contrary, as noted above, both Roe and Webster hold that the state has a compelling interest in preserving the fetus as a "potential" person regardless of its actual personhood. This is the proposition I shall attempt to refute in Part II. Let us carefully review, therefore, the relevant passages in Roe and Webster.

Were the fetus a person, the Roe Court acknowledged, a compelling state interest would undoubtedly exist. ${ }^{36}$ The Court stressed, however, "the wide divergence of thinking on this most sensitive and difficult question."37 Doctors, the Court observed, differed on the subject. Some viewed conception as the moment at which human life begins, others viability, and still others birth. ${ }^{38}$ Religious groups also took sharply contrasting and in some cases internally inconsistent positions. ${ }^{39}$ Finally, the common law did not treat

34. See, e.g., Hudgens v. NLRB, 424 U.S. 507 (1976).

35. See text accompanying notes $25-28$ supra. An argument has been made for abortion rights even assuming that the fetus is a person. See, e.g., L. TRrBe, supra note 6, at 129-35; Donald H. Regan, Rewriting Roe v. Wade, 77 Mich. L. REV. 1569 (1979). Both of these commentators draw heavily on Judith Thomson, A Defense of Abortion, 1 PHL. \& PUB. AFF. 47 (1971), who suggests that sustaining the life of another person physically attached to one's body is an act of good samaritanship-virtuous but not obligatory according to conventional norms. Whether or not Thomson's argument succeeds, it hardly follows that states cannot constitutionally require act3 of good samaritanship, particularly where lives (or compelling state interests in general) are at stake. So far as I know, the Constitution does not enact Spencer's "The Proper Sphere of Government" any more than it does his Social Statics. As to the further claim that requiring a "good samaritan" duty in the abortion context violates the equal protection clause, I do not see how this advances the argument. Equal protection also yields in the face of compelling state interests. See note 31 supra; see also LAURENCE H. TRIBE, AMERICAN ConstrTutional LAW \& 15-10, at 1356-57 (2d ed. 1988) (criticizing Regan's position); Ronald Dworkin, The Great Abortion Case, N.Y. REv., June 29, 1989, at 49,50 (same). We shall assume, at any rate, that determining a fetus to be a person would, with certain very limited qualifications, entitle a state to prohibit abortion.

36. Roe v. Wade, 410 U.S. $113,156-59$ (1973).

37. Id. at 160 .

38. Id.

39. For example, the Court noted that the Roman Catholic Church hed until the mid-nine- 
fetuses as persons "in the whole sense" at least until "quickening," and in many cases not until birth. ${ }^{40}$

The Court drew two conclusions from these observations. First, it stated that the judiciary could not be expected to resolve the problem of fetal personhood. "When those trained in the respective disciplines of medicine, philosophy, and theology are unable to arrive at any consensus, the judiciary, at this point in the development of man's knowledge, is not in a position to speculate as to the answer." 41 Second, and still more important, the Court held that state legislatures as well were not in a position "to speculate" about fetal personhood. "In view of [the wide divergence of thinking], we do not agree that, by adopting one theory of life, [a state] may override the rights of the pregnant woman that are at stake." 42

Thus disposing of the question of when a fetus becomes an actual person, ${ }^{43}$ the Court went on to hold that the fetus nevertheless represented the potentiality of a person, and that there was an "important and legitimate [state] interest in protecting the potentiality of human life."44 This interest, the Court ruled, becomes "compelling" when the fetus reaches "viability," the point at which the fetus "has the capability of meaningful life outside the mother's womb." 45 Consequently, only after viability could abortion be pro-

teenth century taken the position that life begins upon fetal "animation," but subsequently insisted upon conception as the relevant event. Id. at 160-61. As to the time when the fetus became "animate," Catholicism followed Aristotle, holding that animation occurred at about 40 days in the case of male fetuses and at about 80 days in the case of females. Id. at 133-34. By contrast, the predominant Jewish and Protestant view was said to be that the fetus does not attain personhood until birth. Id. at 160 .

40. Id. at 132-36.

41. Id. at 159.

42. Id. at 162 .

43. An entirely distinct question of fetal personhood is whether the fetus is a "person" within the meaning of the fourteenth amendment. The Roe Court answered this question in the negative. Id. at 158.

Professor Dworkin, supporting the Court's conclusion on this point, has suggested that this issue disposes of the abortion question altogether. See Dworkin, supra note 35, at 49. "[N] state," he argues, "is free to deny or substantially curtail rights the Constitution does establish by recognizing rights, or right bearers, that it does not." Id. at 50 n.6. Thus for Dworkin, as for Tribe and Ely, see note 6 supra, the fetus's actual personhood is irrelevant to a woman's right of abortion: A state could ban abortion only if fetuses were "constitutional persons" in the sense just described. Id. at 49.50.

Dworkin's position seems difficult to maintain. The Supreme Court has in other contexts recognized compelling state interests that do not appear to reflect rights "establish[ed]" by the Constitution. See, e.g., Sable Communications, Inc. v. FCC, 109 S. Ct. 2829, 2839 (1989) (holding that states have a compelling interest in "preventing minors from being exposed to indecent" speech). But perhaps Dworkin's objection is to the compelling state interest doctrine itself. For so long as we have such a doctrine, it seems quite odd to propose that the Constitution, heretofore understood to establish the rights states must protect, should also be read to establish all the interests that states may protect, even those interests that can become so "compelling" as to permit the curtailment of constitutional rights.

In any event, we shall assume (as did the Court in Roe) that excluding fetuses from the definition of "persons" protected by the due process and equal protection clauses does not resolve the abortion question, because if fetuses may be deemed actual persons, then a compelling state interest would nonetheless be established.

44. Roe v. Wade, 410 U.S. 113, 162-63 (1973) (emphasis added).

45. Id. at 163 . 
scribed. ${ }^{46}$ This occurred around twenty-four to twenty-eight weeks after conception, ${ }^{47}$ or roughly the beginning of the third trimester of pregnancy. The Court made no attempt to explain why states could claim an interest in "the potentiality of human life" or why this interest became compelling only after viability.

The viability standard and trimester-based approach announced in Roe survived without considerable change until Webster. ${ }^{48}$ In Webster, Chief Justice Rehnquist, writing for the plurality, condemned both the "key elements of the Roe framework-trimesters and viability."49 The plurality stated: "[W]e do not see why the State's interest in protecting potential human life should come into existence only at the point of viability, and that there should therefore be a rigid line allowing state regulation after viability but prohibiting it before viability."50 Endorsing language from the dissenting opinions in a prior abortion case, the plurality held that the state had a " "compelling interest' in protecting human life throughout pregnancy."s1

The Webster plurality, like the Roe majority, refrained from rendering any determination about the personhood of a fetus. In Webster as in Roe, the fetus's status as a "potential life" was held to be a sufficient predicate for finding a compelling state interest that permitted the regulation of abortion. The crucial difference is that according to Roe, this compelling interest begins only upon viability, whereas according to the Webster plurality, it begins upon conception.

Although the Webster plurality claimed that it had declined to pass upon the fundamental holding of Roe,52 Justices Scalia and Blackmun appear to be quite correct in asserting that the plurality's opinion, if taken to its logical conclusion, implicitly overrules that holding. ${ }^{53}$ Once a compelling state interest in the fetus is recognized upon conception, it seems clear that under current doctrine a complete prohibition of abortion would have to be upheld. ${ }^{54}$

46. Id. at 160 .

47. See id. at 163-65.

48. Webster v. Reproductive Health Servs., 109 S. Ct. 3040 (1989). Webster upheld, inter alia, a state law requiring doctors to perform certain tests to determine viability. A plurality of three justices found that this law contravened the Roe framework because the tests would be performed on some previable fetuses. Id. at 3056. The plurality took advantage of the opportunity presented by this conclusion to overrule Roe in part. Id. at 3056-57. Justice O'Connor saw no conflict with Roe, but concurred in the Court's judgment. See id. at 3060-61 (O'Connor, J., concurring). Justice Scalia also concurred, but on the ground that Roe should be overruled in toto. See id. at 3064 (Scalia, J., concurring). Justices Brennan, Marshall, Blackmun, and Stevens dissented.

49. Id. at 3056-57.

50. Id. at 3057.

51. Id. (citing Thornburgh v. American College of Obstetricians and Gynecologists, 476 U.S. 795 (1986) (White, J., dissenting); id. at 828 (O'Connor, J., dissenting)).

52. Webster, $109 \mathrm{~S}$. Ct. at 3058.

53. Id. at 3064 (Scalia, J., concurring); id. at 3077 (Blackmun, J., dissenting).

54. Id. at 3076-77 (Blackmun, J., dissenting) ("Since, in the plurality's view, the State's interest in potential life is compelling as of the moment of conception, and is therefore served only if abortion is abolished, every hindrance to a woman's ability to obtain an abortion would be constitutional."). Confirming Justice Blackmun's prediction, the Justices who formed the Webster plurality (together with Justice Scalia) have more recently indicated that they would apply a mere rationality test to 
Should the Court eventually draw this conclusion from Webster's premises, Roe itself will have been partially to blame. It was Roe that recognized a compelling state interest in protecting potential human life, and if there can ever be such an interest, then the Webster plurality is quite right to question why it should be marked at viability rather than at conception. To be sure, viability can be viewed as a point at which a "potential life" comes an important step closer to actuality; but a pre-viable fetus is no less a potential human being just because current medical technology is not yet sufficiently advanced to allow it to continue its development outside the womb. ${ }^{55}$ Moreover, so long as the fetus is considered solely as a potential person, the state's interest remains substantially the same before and after viability. At either stage, the state is confronted with a potential human life, whose capacity to become actual can only be preserved through a ban of abortion. ${ }^{56}$

Moreover, in a framework based on the fetus's status as a potential life, to focus on the point of viability within the progress of a pregnancy seems precisely to cut against Roe's ultimate holding. For if the state interest supporting antiabortion laws is the preservation of potential life, surely the state's justification for prohibiting abortion is stronger prior to viability, when an abortion will necessarily destroy that potential. ${ }^{57}$ The problem is, quite simply, that Roe's viability holding cannot be squared with its "potential life" premises. ${ }^{58}$

Suppose, therefore, we concede that the Webster plurality has the better of the argument in this limited but critical respect. The plurality's opinion nonetheless rests on the unexplained proposition, taken directly from $R o e$, that abortion laws can be predicated upon a compelling state interest in pre-

abortion regulations. See Ohio v. Akron Center for Reproductive Health, 110 S. Ct. 2972, 2983-84 (1990) (plurality opinion).

55. See Akron v. Akron Center for Reproductive Health, 462 U.S. 416, 460-61 (1983) (O'Connor, J., dissenting).

56. In support of Roe, it is often said that the chances of spontaneous abortion are quite high early in a woman's pregnancy. See, e.g., Susan R. Estrich \& Kathleen M. Sullivan, Abortion Politics: Writing for an Audience of One, 138 U. PA. L. REv. 119, 146 (1989); Langerak, Abortion: Listening to the Middle, in ETHICAL Issues IN MODERN MEDicine 174, 177-79 (J. Arras \& R. Hunt eds. 2d ed. 1983). But which way does this argument cut? Surely it is not the state's interest in potential life, but the woman's interest in deliberately aborting her pregnancy, that most directly increases as the chances of a spontaneous abortion diminish. At any rate, the state's interest in the fetus qua potential human life-assuming it has such an interest at all-does not seem to increase during pregnancy. It is rather the probability (or the proximity) of the fulfillment of this interest that increases.

57. After viability, one might even argue, the state would be obliged to permit women to terminate a pregnancy, provided that the procedure allowed the fetus a chance to survive. See, eg., John A. Robertson, Medicolegal Implications of a Human Life Amendment, in DEFINING HuMAN LIFE: Medical, LegAL, AND ETHiCAl Implications 161, 166 (M. Shaw \& A. Doudera eds. 1983).

58. The difficulty of maintaining Roe's position is reflected in Justice Blackmun's dissent in Webster, where instead of offering an argument, he could only insist that "the viability standard takes account of the undeniable fact that as the fetus evolves into its postnatal form, and as it loses its dependence on the uterine environment, the State's interest in the fetus' potential human life ... becomes compelling." $109 \mathrm{~S}$. Ct. at 3075 (Blackmun, J., dissenting) (emphasis added). The proposition that the state's interest in potential life becomes "compelling" at any gestational point is not a factual matter, and the proposition that it becomes compelling at viability is hardly undeniable. 
serving "potential human life." And this proposition, as we shall sæe below, cannot be defended.

Let us pause for one moment, however, to take account of a position somewhere between Roe and Webster that Justice O'Connor has sought to stake out in a series of separate opinions.

Alone among those justices who concurred in Webster, Justice O'Connor voiced serious reservations in that case about a wholesale overruling of Roe. ${ }^{59}$ Despite her criticisms of Roe's trimester approach ${ }^{60}$ and her apparent agreement with the plurality's view that states have a compelling interest in "potential" human life "throughout pregnancy,"61 Justice O'Connor has suggested a framework in which abortion regulations would be upheld unless they imposed an "undue burden on a woman's abortion decision." 62

The problem for Justice O'Connor is the seeming conflict between holding that states have a compelling interest in potential life from conception and maintaining any caution about overruling Roe. Justice Scalia, in his surprisingly vituperative concurrence in Webster, denounced Justice O'Connor's proposed burdensomeness standard as "irrational."63 In Justice Scalia's view, to recognize a compelling state interest in potential life throughout pregnancy is "effectively [to] overrule Roe," which he believed should have been done "explicitly." 64

Quite possibly, however, Justice O'Connor has in mind an understanding of the state's interest in potential life less rigid than the current dichotomy between "compelling" and "noncompelling" interests permits-either allowing or disallowing regulation. Despite believing that the state's interest in potential life cannot be limited to the viable fetus, Justice $O^{\prime} C o n n o r$ nonetheless seems troubled about holding that this interest automatically entitles a state to supersede the woman's right of privacy. Although this leaves her in an awkward position from the standpoint of current doctrine, we shall see whether Justice O'Connor's or Justice Scalia's view is ultimately more defensible.

\section{The State's Interest In Potential Life}

As we have seen, the fetus's status as a "potential human life" has been the foundation of the state's power to prohibit abortion since the Court de-

59. Id. at 3061 (O'Connor, J., concurring).

60. See Akron v. Akron Center for Reproductive Health, 462 U.S. 416, 458 (1983) (O'Connor, J., dissenting).

61. Thornburgh v. American College of Obstetricians and Gynecologists, 476 U.S. 747, 828 (1986) (O'Connor, J., dissenting) (quoting Akron, 462 U.S. at 461 (O'Connor, J., dissenting)).

62. Webster v. Reproductive Health Servs., 109 S. Ct. 3040, 3063 (1989) (O'Connor, J., concurring). Justice $O^{\prime}$ Connor's standard, to be precise, is that abortion regulations not imposing such an "undue burden" would be upheld so long as they were rationally related to a legitimate state purpose. See Hodgson v. Minnesota, 110 S. Ct. 2926, 2949-50 (1990) (O'Connor, J., concurring); $A k$ ron, 462 U.S. at 453, 462 (O'Connor, J., dissenting).

63. Webster, $109 \mathrm{~S}$. Ct. at $3066 \mathrm{n} .^{*}$ (Scalia, J., concurring).

64. Id. at 3064; see also, e.g., Ohio v. Akron Center for Reproductive Health, 110 S. Ct. 2972, 2984 (1990) (Scalia, J., concurring) (advocating the overruling of Roe). 
cided Roe v. Wade. In this section, therefore, we put aside the question of the point at which the fetus can be deemed an actual person, and instead consider the fetus solely as a "potential" person. Even as we set this question aside, however, we must proceed with caution: What exactly are we setting aside?

At the point in our ontogeny where an independent human life-a person-is recognized, a being with distinct ends and interests of its own must then be reckoned with. As we saw earlier, the authority of the state to protect an individual's personal or property rights is usually presumed, even when doing so impedes the exercise of others' constitutional rights. Accordingly, if the fetus were deemed a person, a state could justify antiabortion laws on the basis of the fetus's own interests as a rights-bearing human being. Thus, by putting the personhood of the fetus momentarily aside, we are for the time being precluding the state from claiming that the fetus's rights as a human being provide the requisite compelling state interest.

However, as John Ely pointed out shortly after the Court decided Roe, no rule or doctrine holds that a compelling state interest can exist only when harm to a person is threatened:

Dogs are not "persons in the whole sense" ..., but that does not mean the state cannot prohibit killing them: It does not even mean the state cannot prohibit killing them in the exercise of the First Amendment right of political protest. Come to think of it, draft cards aren't persons either. ${ }^{65}$

Ely's remarks emphasize the point that, as a logical matter, the killing or destruction of things other than persons can equally impinge on state interests to such a degree that the state may prohibit conduct otherwise protected by constitutional rights. Ely may, however, have underestimated the difficulties inherent in explaining what the alternative compelling state interests could be in the case of abortion. Let us look more carefully at his examples, which are quite instructive.

An analogy to animal rights in the abortion context has a superficial appeal, but is in reality very troublesome. To be sure, the analogy reminds us that humans are not the only beings that can be said to have interests or even rights. But the relevance of this point to abortion is unclear. To understand the fetus as a "potential life" is not to understand it as an actual, but less than human, animal. And the right-to-life movement is hardly dedicated to elevating the fetus to the status of a housepet.

But what, in any event, is the legal status of a housepet? Even if human fetuses were deemed to have this status prior to their personhood, it would by no means follow that abortion could be proscribed. Where is the compelling state interest? Animals are routinely killed in furtherance of mere human desires and impulses, much less constitutional rights. I doubt very much that the interest in protecting an animal, rather than a human, could

65. Ely, supra note 6, at 926 . 
be said to be of sufficient weight to force a woman to bear a child against her will.

It may be true, as Ely suggests, that a state could forbid the killing of certain animals generally and then apply that proscription as a kind of "manner" regulation to someone exercising his first amendment right of protest. But if the effect of the proscription were to destroy the right altogether, as would be the case with respect to abortion, the result would surely be different. Would anyone contend, for example, that a law prohibiting all mass political demonstrations could be predicated on a compelling state interest in animal life, even upon proof that a certain number of ants (or, for that matter, stray dogs) would necessarily be killed by the throng? ${ }^{66}$

Let us turn to Ely's comment about draft cards. As this remark suggests, even if a fetus has no interests as an end-in-itself, the state might still have independent interests in protecting it. When the Supreme Court upheld the prosecution of draft card burners, the state interest at issue was not some inherent right against burning enjoyed by the cards as ends-in-themselves, but the preservation of the military service selection system in which these cards played a functional role. ${ }^{67}$ Thus the state may have its own legitimate interests that qualify as compelling entirely apart from the protection of any particular individual's personal or property rights.

The question therefore becomes whether the state has interests of its own in the "potential life" of the fetus, apart from any interests the fetus might have if it could be deemed a person. And the answer is indisputably yes. There are a number of clearly identifiable state interests in the fetus qua potential life. Whether these interests could support a prohibition of abortion is a different matter.

First, without doubt the state has a legitimate interest in ensuring the health of delivered infants, if for no reason other than that unhealthy children may tax important social resources. But this interest, whatever its strength, ${ }^{68}$ depends on the baby actually being born. It does not apply in the abortion context, for the simple reason that an abortion results in no birth.

Second, the state has an equally clear interest in the size of its population, an interest raising numerous, complex issues. Among these, perhaps the most difficult is the question of whether the need to decrease population growth could form a constitutionally sufficient basis to impose limits on childbearing. Prohibitions of abortion, however, do not raise this problem.

66. Ely's law would be a "manner" regulation in that the protester would presumably have alternative means of exercising his constitutional rights. $C f$., e.g., Clark v. Community for Crestive Non-Violence, 468 U.S. 288 (1984) (upholding prohibition of sleeping in public park as a valid "manner" regulation of individuals protesting policies on homeless). But a pregnant woman has no alternative means of exercising her right. As Professor Tribe has succinctly put it, "Nobody has to kill an animal . . . in order to exercise the right to engage in freedom of speech," but if a woman chooses to have an abortion, "she has no alternative other than [to end] the fetus's life." L. TruBE, supra note 6, at 114-15 (original emphasis).

67. See United States v. O’Brien, 391 U.S. 367 (1968).

68. See Developments in the Law-Medical Technology and the Law, 103 HARv. L. REv. 1519, 1556-84 (1990) (student author). 
At most, one might ask whether antiabortion laws could be justified on the basis of a compelling state interest in increasing the size of our population. This question is much easier to dispose of: There is no such compelling state interest. ${ }^{69}$ And even if there were, an antiabortion law surely could not be sustained as a "narrowly drawn"70 means of furthering it.

Finally, there is another constellation of putative state interests surrounding the fetus, considered as a potential life, that may loosely be called social engineering interests. The importance of these interests in the abortion context should not be underestimated. They include preserving women's traditional roles as wife and mother as well as shaping the genetic make-up of individuals' offspring. These interests, if a state may properly invoke them, would strongly support governmental intervention in women's child-bearing decisions (including the decision of whom to beget children with). But surely these interests are constitutionally illegitimate; they contradict the very principle of privacy. ${ }^{71}$ To set up such interests as counterbalancing factors that could outweigh the privacy right would be like relying on a state interest in brainwashing the populace in order to override the first amendment.

And isn't that the end of the matter, so long as the fetus is considered solely as a potential rather than an actual life? The state has no compelling interests of its own in protecting this potential life from being aborted, and the fetus, qua potential life, has no interests as an independent person that the state can claim to be protecting.

But perhaps we have been too hasty in supposing that a fetus, considered only as a potential life, has no interests of its own. Someone will say that a potential life at least has potential interests, and that having potential interests cannot be equated with having no interests at all. One of our assumptions, after all, has been that the compelling state interest test can be satisfied by a showing that the conduct the state seeks to forbid would violate generally protected legal interests. Are there not numerous instances in which the law affords protection to potential interests?

Certainly, there are identifiable, protectable, and indeed protected interests that might be called potential in nature. For example, although I have never met any remaindermen, I am quite sure they have legally enforceable interests in the estates they may one day possess. But this sort of "potential

69. See Webster v. Reproductive Health Servs., 109 S. Ct. 3040, 3084 (1989) (Stevens, J., concurring) ("No one argues today, however, that Missouri can assert a societal interest in increasing its population as its secular reason for fostering potential life.").

70. "The Court has held that regulation[s] limiting [fundamental] rights . . . must be narrowly drawn to express only the legitimate state interests at stake." Roe v. Wade, 410 U.S. 113, 155 (1973).

71. See Jed Rubenfeld, The Right of Privacy, 102 HaRv. L. Rev. 737, 782-92, 794, 807 (1989) (privacy right is the "right not to have the course of one's life dictated by the state," $i d$. at 807); see also L. TRIBE, supra note 6, at 101-03 (stating that the right to privacy "guarantees each of us the right not to have the state shackle us with self-defining decisions"). It should be noted, in any event, that these "state interests" would apply equally to contraception. 
interest" is quite different from that on which a state would have to rely in support of a law proscribing abortion.

The potential interests of a remainderman are cognizable only on the assumption that these interests may at some point become actual. On the same assumption, without deeming a fetus to be an actual person, we could still speak of its potential interests in someone's will, in being born to a mother who wants her child, or more generally in the condition of the world into which it will be delivered. All such potential interests are, however, contingent on the potential person's becoming an actual person with actual interests. They are contingent, in short, on the fetus's birth.

To speak of a fetus's interest in being born would be a very different proposition. We would then have to ascribe to the potential life an actual interest in actualization itself. But unlike a living remainderman, a potential life has no actual interests whatsoever; at most it has "potential interests," by which is meant interests that may become actual-interests that the potential life would have if it became actual. I am not saying that we cannot logically conceive of a fetus having an actual interest in being born, in avoiding pretermission, or in a host of other things. We certainly can, but the moment we do, we have moved beyond "potential life" and are now imagining the fetus as an actual, independent being.

This is not mere logomachy: A potential thing cannot be said to possess the very attributes that distinguish it from the actual. Ice, potentially a liquid, does not conform to the shape of a container to which it is transferred; if it did, we would be obliged to admit it was already a liquid. The distinguishing feature of personhood is this: A person has interests as an end in himself that command our moral respect, and a person's life commands a degree of respect above and beyond any other worldly thing. To ascribe these characteristics to a "potential" person is, sub silentio, nothing other than to convert the potential into the actual.

If doubt remains, consider the extraordinary consequences of ascribing to potential human life an actual interest in being born. The potential children of a proposed marriage are potential persons too. The unfertilized ovum that may be fertilized on any given night also represents a potential human life. ${ }^{72}$ What are the implications of ascribing to each of these potential lives an actual, protectable interest in being born?

A supporter of the Webster plurality will argue that an "actual potential" human life, or some such thing, does not come into existence until conception. But this is the same mistake for which the Webster plurality took Roe to task. Conception, like viability, brings the "potential life" an important step closer to actualization, but the "potentiality of human life" clearly exists before as well as after these two events. I repeat: We cannot ascribe to potential life an actual interest in anything-and certainly not in its own life-unless, of course, we are covertly deeming it to be actual rather than

72. See, e.g., Joel Feinberg, The Rights of Animals and Unborn Generations, in RIGHTs, JusTICE, AND THE BOUNDS OF LIBERTY 159, 183 (1980). 
potential life. ${ }^{73}$

I suppose it might yet be said that after conception there is something more "concrete" in existence or that a "natural" process of development has begun, differentiating an embryo from pre-conception potential lives, and allowing us to regard the embryo as somehow "more actual." But there is nothing abstract about pre-conception potential lives. Their cells can be as biologically real and identifiable as those of a blastocyst. Obviously an unconceived potential life requires external resources and certain acts by actual persons before it can become an actual life, but that is equally true of an embryo. ${ }^{74}$ Moreover, the reliance on a "natural process" of gestation and delivery to distinguish embryos from pre-conception potential lives is specious. Sex is a "natural process" too. Hence any interference with sexwhether one treats contraception or marriage as the source of that interference-would prevent a potential life's "natural" progress toward actualization in the very same way that abortion does.

Thus "potential life" does not begin at conception any more than it begins at viability. Accordingly, if the state has a compelling interest in protecting "potential life," profound consequences follow. A state could forbid not only abortion, but contraception as well. More than this, a state could compel individuals to marry or procreate with specified individuals and at specific times, all in the name of protecting potential lives. If potential life has an interest in being born, and if the state can invoke that interest to supersede the right of privacy, these possibilities, which may or may not be farfetched, would be well within the arguable scope of constitutional legislation.

Indeed, these consequences follow from the claim that states can assert a compelling interest in potential human life regardless of what we say about fetal "rights." Whether the source of the state interest lies in population control, social engineering, or the right of a potential person to become actual, to recognize a compelling state interest in "potential lives" is to subject to government regulation every one of our decisions about whom we marry or the conditions under which we procreate. Let us hope, then, that Justice O'Connor is indeed hesitant to recognize a compelling state interest in potential life that would automatically supersede the right of privacy. Her associates on the Court who wax vitriolic about the motes in her logic might do better to reflect upon the planks in their own.

73. Nor could a Webster supporter argue that the state's interest in potential life increases as actualization approaches. Or rather, he might make this argument, but he would then have to give up his quarrel with Roe's viability holding. See Frances Olsen, Unraveling Compromise, 103 HARv. L. REv. 105, 126-27 (1989); see also note 56 supra (suggesting that state's interest in prohibiting abortion to protect potential life does not increase as pregnancy progresses).

74. See Olsen, supra note 73 , at 127-28. Note that we are not here dealing with the claim that actual life, or personhood, begins upon conception. As to that claim, the genetic completion achieved at fertilization arguably does become relevant. See text accompanying notes 112-113 infra. Here, the question is solely whether the "potentiality of human life" begins upon conception, to which the answer is plainly no. 


\section{The Personhood of the Fetus}

Grant, then, that no interest in "potential life" permits a state to prohibit abortion-at any stage of pregnancy. Abortion can be prohibited only when a state is permitted to look upon the fetus as an actual person, with an actual interest in its own life. If this is so, then there is no evading the question of the fetus's personhood. In order to uphold any proscription of abortion-or to strike one down-a court must decide when a state may deem the fetus an independent human being. ${ }^{75}$

But if the abortion question boils down to a determination concerning the fetus's humanity, then considerations of judicial competence may become pressing. "Judicial deference," it will be said, "is not only the wisest course; it is the only course. Your entire argument supports those of us who have always maintained that the judiciary can have nothing to say about abortion."

Why has the question of the fetus's humanity been met by such a steadfast silence in the Supreme Court? Perhaps such discretion is justified; if so, then we have reached an impasse and must give up our inquiry here. Thus, we are obliged to analyze this jurisprudential silence before we are entitled to break it.

\section{A. That the Judiciary Must Address the Question}

Four principal claims can be made to explain why silence is the only sound judicial response on the subject of fetal personhood. Let us consider them one at a time.

1. "It is a matter of faith, and the Constitution can have nothing to say about it."

To be sure, the point at which human life begins is an article of faith in certain religions. But it does not follow that constitutional law must therefore be silent. To the contrary, if the question were solely a matter of religion, then the establishment clause would preclude states from enacting any particular answer into law. ${ }^{76}$

This is not to say that no state may enact an abortion law in conflict with someone's religious beliefs. But to do so, a state must have legitimate secular interests supporting its legislation. ${ }^{77}$ Here, as we have seen, determining the fetus's humanity is a prerequisite to establishing a sufficient secular interest. If this determination were in turn solely a religious one, then no prohibition of abortion could be sustained. Far from requiring constitutional deference

75. Again, we are assuming a doctrinal framework in which the privacy right in general and the contraception cases in particular have not been repudiated. See notes 20-22 supra and accompanying text.

76. Justice Stevens seems to think the question of life's beginning is solely a religious one and, given that premise, correctly draws this conclusion. See Webster v. Reproductive Health Servs., 109 S. Ct. 3040, 3082-83 (1989) (Stevens, J., dissenting).

77. E.g., Lemon v. Kurtzman, 403 U.S. 602 (1971); L. TRIBE, supra note 35, § $14-9$ at $1204-05$. 
to state legislation, the argument from faith militates in favor of the most extreme constitutional resistance to abortion regulations.

\section{2. "It is a matter of personal belief, and state legislation must therefore be deferred to."}

This position substantially refines the first one. The shift from "faith" to "personal belief" invokes that amalgam of morality, self-interest, and ideology, loosely called a person's "politics," and eliminates the counter-appeal to the establishment clause that we made a moment ago. Because (the argument goes) the question of life's beginning is a matter of politics, it is clearly a matter for political, not judicial, resolution. ${ }^{78}$

An abortion rights advocate might reply that matters of deeply held personal belief are no different from matters of faith and may not be constitutionally settled by legislation. But this response would be foolish. Legislation constantly decides matters of profoundly contested personal and moral beliefs. That is one of the chief purposes of legislation.

On the other hand, it is equally fatuous for opponents of abortion rights simply to insist that "the tools for this 'job' are not to be found in the lawyer's-and hence not in the judge's-workbox."79 The "tools" for this job are not in anyone's workbox. But a judge is not a handyman, and he cannot call in state legislators as professionals whenever he feels out of his depth. Has anyone ever imagined that the tools to determine what counts as "religion" are ready to the jurist's hand? Yet, when this determination becomes dispositive of first amendment rights, the great difficulty of the question permits the judiciary neither to evade it nor to allow the states to answer it. ${ }^{80}$

In determining that life begins at a certain gestational point, a state establishes a compelling interest and thereby delineates the outer limit of a constitutional right. Courts cannot simply defer to state law on this point. They can no more defer here than in the case of a state's enactment of a certain definition of "clear and present danger" allowing the legislature to prohibit constitutionally protected speech. ${ }^{81}$

Thus, Justice Scalia has it exactly backward when he says, distinguishing Roe from Griswold and Eisenstadt, that there can be no constitutional right to abortion "without volunteering a judicial answer to the nonjusticiable question of when human life begins." 82 To the contrary, given the contra-

78. See, eg., Webster, $109 \mathrm{~S}$. Ct. at 3064-66 (Scalia, J., concurring) (inveighing against "this Court's self-awarded sovereignty over a field where it has little proper business since the answers to most of the cruel questions posed are political and not juridical," id. at 3064); Richard A. Epstein, Substantive Due Process By Any Other Name: The Abortion Cases, 1973 SuP. CT. REv. 159, 175.

79. Hodgson v. Minnesota, 110 S. Ct. 2926, 2960 (1990) (Scalia, J., concurring in the judgment in part and dissenting in part).

80. See, e.g., United States v. Sun Myung Moon, 718 F.2d 1210, 1227 (2d Cir. 1983) (defining "religion"), cert. denied, 466 U.S. 971 (1984). See generally L. TRIBE, supra note 35, §146 at 117983 (discussing judicial definitions of religion in first amendment contexts).

81. See, e.g., Landmark Communications, Inc. v. Virginia, 435 U.S. 829, $842-45$ (1978).

82. Ohio v. Akron Center for Reproductive Health, 110 S. Ct. 2972, 2984 (1990) (Scalia, J., concurring). 
ception cases, a right to abortion cannot be denied without volunteering a judicial answer to the question of when human life begins.

To see why this is so, suppose a state declared that personhood ends at sixty-five and on that basis withdrew all protection of life, liberty, and property from individuals over that age. Or suppose an overpopulated state embarked on a campaign of infanticide, supporting its measures with the determination that human life did not begin until age five. Personhood is not and cannot be a "political question." It is a question, indeed the question, of who holds legal rights. When the rights at stake are constitutional, state legislatures plainly are not entitled to the last word. Quite apart from the right of privacy, the Constitution lodges in the judiciary the ultimate responsibility to oversee state determinations of personhood.

For this reason, deference to a state's determination that life begins at conception is a judicial answer to Justice Scalia's "nonjusticiable" question of when human life begins. Would Justice Scalia permit states to deem life to begin upon ovulation and on that basis ban contraception or even require insemination? Presumably not. Would he permit infanticide upon the kind of state determination referred to above? If, as I assume, the answer is again no, but if Justice Scalia is prepared to say that, within the gestational process, states are free to determine the advent of human life as they choose, that simply means that his judicial answer to this "nonjusticiable" question is that human life may properly be deemed to begin upon conception. Abortion cannot be flatly prohibited unless the judiciary either (1) abdicates its constitutional responsibility to oversee state determinations of personhood, or (2) concurs that fetuses may be regarded as persons from the moment of conception.

3. "The question of when life begins is beyond human knowledge, and therefore the judiciary can only draw scorn upon itself by trying to answer it."

This position, ${ }^{83}$ the least clear in its premises, must be admitted to have a certain attraction. The mystery of life's creation, whether understood religiously or otherwise, is not something to be eagerly sacrificed to judicial ratiocination, even that of the wisest judges. Once again, however, the passage of antiabortion laws forces the judicial hand. If state legislatures were silent on the abortion question, so too might be the judiciary. Confronted with laws attempting to qualify a constitutional right, the courts have no choice but to address the question, imperfect though their answer might be.

At the same time, an important qualification is in order. The judiciary is obliged to decide when, at the earliest, a state can deem the fetus to be a person. As we shall see, this is not the same as saying that the Court must itself decide when (if ever) a fetus is in fact a person. ${ }^{84}$

83. For a version of this position, see Epstein, supra note 78, at 175.

84. See texts accompanying notes $97,110-118$ infra. 
4. "The question of when the fetus becomes a person is a matter of fact on which courts have no competence whatsoever. Thus the Constitution cannot preclude a state from adopting any reasonable medical determination, including the determination that life begins at conception."

This final position is the strongest of the four. What do judges know about the facts of embryology? There is ultimately only one response to this objection, but that response is decisive: The point at which a fetus attains personhood is not a question of fact.

\section{B. That the Question is Not One of Fact}

Let us begin with two limiting propositions: First, that the advent of human life takes place no earlier than conception; second, that it takes place no later than birth. Although both these propositions command widespread acceptance, either could in principle be challenged. For purposes of this essay, however, they simply will be accepted as postulates.

We know, then, that at some point between conception and birth-including either of those events, which must themselves be broken down into smaller and more precisely defined moments ${ }^{85}$ - a thing comes into being that we must treat as a person. Let us briefly set forth the relevant facts to see what they can tell us about where to draw a line.

Within a short time after insemination, a man's gamete may meet with and penetrate a woman's ovum. If so, fertilization takes place, a process of about twenty-four hours' duration in which the haploid chromosome sets of the respective gametes commingle to create a single-celled embryo with a full, normal complement of forty-six chromosomes. ${ }^{86}$

After about a week, the embryo may implant itself in the woman's uterine wall. If it does not, no pregnancy occurs and the embryo is lost. Estimates vary, but it appears that at least one half of all fertilized ova do not become implanted. ${ }^{87}$

Until about two weeks after fertilization, the implanted embryo may still split into multiple entities (twins, triplets, and so forth). In rare cases, the opposite can occur-sibling embryos may fuse and develop into a single person who, though otherwise perfectly normal, carries two genetically distinct sets of cells. ${ }^{88}$ By eight weeks, the embryo has developed discernible fingers and toes. By ten weeks, all human organs are present in rudimentary form, ${ }^{89}$ and inchoate electrical activity is detectable in the embryo's brain cells. ${ }^{90}$

85. See note 112 infra.

86. See, eg., Jack A. Pritchard \& Paul C. McDonald, Williams Obstetrics 79-84 (15th od. 1985).

87. See id. at 89-92; Postcoital Contraception, 1 LANCET 855, 856 (1983).

88. See L. TRIBE, supra note 6, at 118.

89. See, eg., J. PRITChARD \& P. MCDONALD, supra note 86, at 145.

90. Robert J. Sokol \& Mortimer G. Rosen, The Fetal Electroencephalogram, 1 CuINICs OBSTETRICS \& GXNECOLOGY 123 (1974). 
Apart from the brain, development after the twelfth week can generally be viewed as a matter of growth, rather than the formation of new structures. The fetal brain, however, begins a period of rapid development between about the nineteenth and thirtieth week. Only at the twenty-second to twenty-fourth week does the fetus's cerebral cortex begin to mature, both structurally and functionally.91 At about the same time, the fetus's lungs become capable of respiration. At this point, given current medical technology, the fetus can in many cases be made to survive ex utero. ${ }^{92}$

Sometime around the thirty-eighth week-with a good deal of variation-natural birth occurs. The emerging infant remains connected to its mother's umbilical cord, which, until parturition, is its sole source of oxygen. The cord is cut, and the baby thereupon takes its first breath. ${ }^{93}$

Where in this process shall we say that the fetus attains personhood? Upon fertilization, when a sort of genetic completion might be said to be reached? ${ }^{94}$ At around the twenty-second to twenty-fourth week, when the organ of higher mental functioning begins to mature and when the fetus becomes "viable" given our current medical technology?"5 Or perhaps only upon parturition, when the fetus takes its first breath as a physically independent being?96 Something can be said for all three of these positions or numerous others. The point is that the facts by themselves are not dispositive; it is a question of attaching significance to these facts.

To be sure, I have presented only the most schematic outline of conception, gestation, and delivery. Yet were every fact of human ontogeny perfectly transparent to us, down to the most minute cellular or even molecular interactions, we would still remain in our present position: debating the significance to be attached to certain events, a problem the facts alone cannot resolve.

The tendency to reify personhood-to imagine it as a thing that comes into existence in concrete, factual fashion-may be difficult to overcome. Consider the development of a planted seed into a tree. Even if we knew every fact in this process in complete, scientifically exhaustive detail, we should still have to take a further step to decide at which point we ought to deem the seed, or what was once a seed, a tree. We would have to make a decision, more or less arbitrary, about our concept of "tree" in order to choose a particular point in this process, after which we would say that this rhizoid growth or tiny shoot or sapling was a tree.

The concept of "person" embraces a degree of complexity far greater than that of "tree" and therefore requires more than an act of mere defini-

91. See notes 108-110 infra.

92. See, e.g., Nancy K. Rhoden, Trimesters and Technology: Revamping Roe v. Wade, 95 YALE L.J. 639, 658, 661 (1986); Survey of Abortion Law, 1980 ARIZ. ST. L.J. 67, 130-31 (stating that pulmonary function capability, not weight, is the most important determinant of extra-uterine survival).

93. See, e.g., J. PRITChARD \& P. MCDonald, supra note 86, at 339-40.

94. See text accompanying notes 111-113 infra.

95. See text accompanying notes 99-110 infra.

96. See text accompanying notes 97-98 infra. 
tion. The concept "person" is ineluctably normative; it is not given by facts or by definition alone, but by a normative judgment operating definitively on certain sets of facts. Certainly, in many cases whether we have a "person" before us may appear a factual question not open to any normative dispute. For instance, it is not ordinarily controvertible whether an adult human being is a person, and our certainty in this regard may give the misleading impression that personhood is a purely factual or objective attribute. But only a short time ago, it remained very much disputed whether a woman or black was a person "in the whole sense." Rejecting such propositions expresses not only our factual beliefs but also moral conviction-that differences of gender and skin color cannot support a differentiation in moral or legal rights. Because of the normative nature of the judgment of personhood, neither medical nor scientific expertise can ever be dispositive. ${ }^{97}$ Hence, no argument can be made that the judiciary must defer to such expertise in answering the question of when states may deem fetal personhood to begin.

What does it mean to think of personhood as a matter neither of religion nor of fact? It means that we must conceptualize personhood in exactly the same fashion as we conceptualize adulthood: as a conclusory term designating a point at which we choose to attach to a developing human a certain legal or moral status. This status will depend not on an inherently dispositive developmental event, but on a combination of the developmental facts and the consequences that follow from the status. Thus, our determinations of "adulthood" may well differ in different contexts-for example, drinking or criminal liability. In each of these contexts, states establish ages for adulthood with reference to diverse practical, political, and ethical considerations, including the potential effects upon others of conferring the status at one age rather than another. Similarly, when determining whether a fetus is a person in the context of inheritance or tort law, states' analysis need not, and should not, be the same as for the same determination in the context of abortion. The question of when personhood begins can be asked in a variety of legal contexts, and the various normative considerations appropriate to

97. Cf. L. TRIBE, supra note 6, at 119-20 (arguing that science is unable to determine when a fetus becomes a person); Olsen, supra note 73, at 128 (asserting that the advent of human life is not "something that can be discovered"); Rhoden, supra note 92, at 671-73 \& n.171 (suggesting that fetal personhood is a normative matter).

Perhaps it will be said that "life" is a factual, biological matter even if "personhood" is normative. See, e.g., John M. Goldenring, The Brain-life Theory: Towards a Consistent Biological Definition of Humanness, $11 \mathrm{~J}$. MED. ETHICs 198, 199 (1985) (purporting to offer a "relatively 'value-free' and objective" determination of human life, as distinct from a "value-laden" concept of personhood, which refers to moral or legal "rights"). But this distinction either (1) renders "human life" an irrelevant term within the abortion debate because what matters is the fetus's acquisition of rights, see note 1 supra, or (2) is entirely specious because the "value-free" concept of human life turns out to include a right to life or to have other crucial moral implications rendering it functionally equivalent to personhood. See, eg., Goldenring, supra, at 202 ("WWith] abortions [after the eighth week] an actual human life is terminated. .. . Proponents must ... recognize that such late abortions end an actual human life and not just a mass of tissue ....") (emphasis added). 
these contexts-including the effects on other parties of conferring the status at one age rather than another-form a decisive element in the analysis.

\section{On the Proposition that "Life Begins at Conception"}

Let us now return to the proposition that "life begins at conception." Before we reach this claim, however, let us first consider two other propositions: (1) that personhood begins at birth; and (2) that personhood begins at viability. No a priori reasoning dictates the choice of these two possibilities; we choose them because they stand out as alternatives that deserve consideration and that may elucidate the analysis. Doubtless, we could envision other possibilities, too.

Can anything be said on behalf of the claim that, for purposes of abortion law, personhood begins at birth? Certainly. It would allow the drawing of a fairly bright line, and it would emphasize the moment in human development when physical independence is achieved.

But the brightness of the line that could be drawn at birth cannot be a weighty factor, since many other bright lines could be drawn at earlier gestational events. Moreover, it would be hard to say that physical independence per se is a necessary attribute of personhood and harder still to deny the strength of that intuition which sees a fully developed fetus as morally indistinguishable from an infant. ${ }^{98}$ I do not say that these observations refute the claim that personhood begins at birth. They merely show its limitations and the moral difficulties it entails.

What about viability?99 As the term is usually understood, viability is a measure of our technology, not the fetus's biology. 100 When scientists perfect an artificial womb, fetuses will be viable throughout pregnancy. Still, certain medical authorities have indicated that our ability to achieve fetal survival ex utero will continue for some time to be dependent upon the fetus's achieving pulmonary capability, which does not occur until about the twenty-third week of pregnancy. ${ }^{101}$ Given this supposedly stable level of technological incapacity, ${ }^{102}$ can viability be defended as the point at which states are permitted to deem the fetus a person?

Considerable difficulties confront this position. Even today, embryos, whether conceived in vitro or in utero, can be implanted into another wo-

98. See, e.g., Patricia A. King, The Juridical Status of the Fetus: A Proposal for Legal Protection of the Unborn, 77 MicH. L. REv. 1647, 1676 (1979); Alan Zaitchik, Viability and the Morality of Abortion, 10 PhIL. \& PUB. AfF. 18, 20-21 (1981).

99. It should be recalled that the Roe Court advanced viability not as the advent of actual human life, but as the point at which the state's interest in potential human life becomes compelling. See text accompanying notes $36-45$ supra.

100. See Rhoden, supra note 92 , at 663-68.

101. "[T] $]$ here is an 'anatomic threshold' for fetal survival of about 23-24 weeks of gestation." Brief for the American Medical Association et al. as Amici Curiae in Webster v. Reproductive Health Servs. at 7, quoted in Webster, $109 \mathrm{~S}$. Ct. $3076 \mathrm{n.9}$ at 3040 (Blackmun, J., dissenting); see also Estrich \& Sullivan, supra note 56, at 142 (describing the conclusions of the New York State Task Force on Life and Law).

102. See, eg., Webster, $109 \mathrm{~S}$. Ct. at $3076 \mathrm{n.9}$ (Blackmun, J., dissenting) ("[T]he threshold of fetal viability is, and will remain, no different from what it was at the time Roe was decided."). 
man's uterus and thereafter carried to term. ${ }^{103}$ This transplantation procedure might suggest that fetuses today are "viable" at the moment of conception. ${ }^{104}$ The response that no technology currently exists to achieve fetal survival between the third day and the twenty-third week of pregnancy ${ }^{105}$ accepts a highly anomalous position: that the embryo is a person for its first three days, then loses its personhood, and then regains it twentythree weeks later. Nor is it satisfactory to answer that viability refers to the fetus's capacity to survive outside any womb, not just the womb of its conception. ${ }^{106}$ This answer threatens to render the concept of viability entirely arbitrary. What difference does it make how the fetus can survive, so long as it can survive outside the womb of the woman seeking to abort it?

In fact, even if we put aside the difficulties raised by embryo transplantation, the normative significance of viability remains elusive. Is there really any difference, at least from the standpoint of personhood, between a fetus's ability to survive through our ministrations and its ability to survive through its mother's? Surely an adult would not lose his personhood if, due to the failure of some organ, he were temporarily unable to survive without attachment to some other person's circulatory system.

Despite these considerable problems, the concept of viability holds a strong normative pull. The advent of personhood is the moment when we regard the fetus as an end-in-itself, a distinct human life-in-being. The effort to draw a line for this purpose should perhaps be an effort to identify a moment when the fetus develops the capacity for some sort of independent life in the world. If we think of viability in terms of this criterion, we may be able to meet the difficulties just raised-but only if we are prepared at the same time to reorient our understanding of viability.

Traditionally understood, viability refers to survivability. Strictly speaking, it refers to the statistical chances of a fetus surviving (into infancy and beyond) if removed at some given time from its mother's womb. ${ }^{107}$ If we are interested in viability as a measure of the fetus's development into a distinct life-in-being, however, we may be more concerned with the kind of life the fetus is capable of at any given time, rather than the length. By "viable" we

103. See, eg., Letter to the Editor from Maria Bustillo, John E. Buster, Sydlee W. Cohen, Fredesminda Hamilton, Ian H. Thorneycroft, James A. Simon, Ingrid A. Rodi, Stephen P. Boyers, John R. Marshall, John A. Louw, Randolph W. Seed \& Richard G. Seed, Delivery of a Healthy Infant Following Nonsurgical Ovum Transfer, 251 J. A.M.A. 889 (1984); Warren A. Kaplan, Fetal Research Statutes, Procreative Rights, and the "New Biology": Living in the Interstices of the Law, 21 SUFFoLK U.L. REV. 723, 728-29 (1987) (student author).

104. See Kaplan, supra note 103, at 753-54.

105. Webster, 109 S. Ct. at $3076 \mathrm{n} .9$ (Blackmun, J., dissenting) (quoting Fetal Extrauterine Survivability, Report to the New York State Task Force on Life and Law 10 (1988)).

106. See Rhoden, supra note 92, at $670 \mathrm{n} .169$ ("Embryo transfer technology, as it exists at present, does not pose problems for the viability standard, because one can readily argue that an embryo is not viable if it must be inside some woman's womb.") (emphasis in original).

107. See id. at 659-60 ("[V]iability in utero is simply the prediction that a particular fetus may survive because infants of its gestational age have previously done so."). As a result, viability has been defined differently according to the survival percentage deemed necessary. See id. at 660-62. 
may mean able to live in a particular way rather than likely to survive for a particular amount of time.

Chances of survival are a dubious measure of personhood. Suppose we knew someone who was probably (or certainly) going to die within a day. His impending death would hardly disqualify him as a person. Similarly, for the purposes of determining a fetus's personhood, likelihood of survival should not be understood as the significant aspect of viability. If, however, viability means the fetus has developed to the point where it can in some important sense live as a human being lives, then perhaps a normatively significant moment has occurred.

And what might this mean, to live "as a human being lives"? To be sure, the "as" in this formulation denotes a certain metaphoricity, and there can no more be an inherent, factual answer to this question than to that of personhood in general. Have we then introduced under the name of "viability" a concept unrelated to anything previously understood by that term? Not necessarily. The stage in human development currently marked by "viability" (in its traditional sense) has always carried an implicit significance quite apart from the fetus's chances of survival. Precisely due to the undeveloped state of our medical technology, "viability" denotes a fairly advanced state in fetal development. Viability occurs not only at the time when the fetus's pulmonary capability begins, but also when its brain begins to take on the cortical structure capable of higher mental functioning. ${ }^{108}$ These two impor-

108. Although the results of prenatal brain research are still imprecise, certain important developments begin at the earliest between weeks 20 and 24 in the cerebral cortex, the part of the brain "generally agreed ... [to] set men apart from other mammals, and mammals from other vertebrates." GoRDON M. ShEPHERD, THE SYNAPTIC ORganization OF tHe BRAIN 339 (2d ed. 1979). "It is not until between weeks 24 and 28 that the cerebral cortex . . . takes on the structure that is characteristic of a normal human being." Rhoden, supra note 92, at $663 \mathrm{n} .134$; see RAYMOND D. Adams \& Maurice Victor, Principles of Neurology 458 (4th ed. 1989); Ronaid J. LEMIRE, JOHN D. LOESER, Richard W. LEech \& Ellsworth C. Alvord, JR., NonMal, aND Abnormal Development. OF THE Human Nervous System 233-39 (1975); Miguel MarinPodilla, Prenatal and Early Postnatal Ontogenesis of the Human Motor Cortex, 23 BRAIN REs. 167, 169,171 (1970) (cerebral cortex of a 20-week-old fetus lacked the "external configuration and the sulcal pattern that characterizes the human brain" and that were evident in a 28-weels-old fetus); Ken Martyn, Technological Advances and Roe v. Wade: The Need to Rethink Abortion Lav, 29 UCLA L. REV. 1194, 1207-08 (1982) (student author).

Perhaps of greatest importance among these structural developments, the interneural connections within the cerebral cortex-which are essential to all higher mental functioning, see G. SHEPERD, supra, at 339-remain quite primitive until the seventh month, when "the major production of synapses commences." R. ADAMS \& M. VICTOR, supra, at 458 (synaptogenesis in cerebral cortex begins between 150th and 180th day); N. Herschkowitz, Brain Development in the Fetus, Neonate, and Infant, 54 BIOLOGY NEONATE 1, 10 (1988) ("The earliest synapses within the cortical plate are seen between 19 and 23 weeks gestation."); D. Gareth Jones, Brain Birth and Personal Identity, $15 \mathrm{~J}$. MED. ETHICs 173, 177 (1989); note 110 infra.

The electrical activity produced by a fetus's brain also undergoes a significant change at this time. Although electrical potentials have apparently been recorded in fetuses beginning between weeks 8 and 14, see Goldenring, supra note 97, at 199; Jones, supra, at 174; Sokol \& Rosen, supra note 90 , this activity is inchoate, highly sporadic and disorganized, see note 110 infra, and may not even be cortical in origin. See Jones, supra, at 177. Minimally organized electrical activity in the cerebral cortex does not begin until 22 to 24 weeks at the earliest. See, eg., JoHN R. HUGHES, EEG IN Clinical Practice 69-70 (1982); K.J.S. Anand \& P.R. Hickey, Pain and Its Effects in the Human Neonate and Fetus, 317 NEw ENG. J. MED. 1321, 1322 (1987) ("[I]ntermittant elec- 
tant developments provide indicia both of independent beingness and of distinctly human beingness.

At the time Roe was decided, "viability" could play this double role, and to some extent it still can. So long as fetal survivability occurs at approximately the twenty-second week, "viability" also refers to the capacity for distinctly human life, for an existence beyond that of a part in a woman's body or its mechanical equivalent. And was it not, after all, perhaps the latter signification that moved the Roe Court when it held that viability mattered because "the fetus then presumably has the capability of meaningful life outside the mother's womb?"109 If we are interested in locating an appropriate point to deem the fetus a person, we must understand viability as the ability to live in some "meaningful" human sense. On that understanding, it becomes a concept concerned with fetal development rather than with medical developments, and the objections raised against it above are answered.

Indeed, perhaps we should go further. We have said throughout that no single answer exists to the question of personhood, and that no biological development inherently brings personhood into being. But this does not mean that no limits can be identified as to the earliest possible moment at which personhood may plausibly be deemed to commence.

Again, adulthood serves as an analogy. Although this status can be conferred earlier or later in varying contexts, there remain limits imposed by the very concept of adulthood-if the concept is to remain normatively meaningful. It would be absurd (and probably unconstitutional) for states to deem adulthood to begin at two. So the recognition that a status like adulthood derives from normative judgment, not merely factual information, does not by any means imply that the facts impose no limits whatsoever.

The concept of personhood may have similar limits. If we genuinely disengage ourselves from the tendency to reify - or to theify-personhood, we must ultimately pin the concept down with criteria pertaining to the distinctive qualities of humanness. To the extent that humans are entitled to moral treatment different from that accorded to animals, unless we are to indulge in pure speciesist prejudice, it must have something to do with our mental capacities-mental here referring not only to our capacity for thought, but also for speech, self-consciousness, moral experience, certain forms of emotion or spirituality, and so on.

Now we may very well differ in our judgment as to which of these capacities is more important to humanness, and we may also differ as to when in human ontogeny the relevant capacities are sufficiently developed to merit the status of personhood. For constitutional purposes, however, we need not try to resolve this problem once and for all; we need only agree that prior to become sustained at 22 weeks and bilaterally synchronous at 26 to 27 weeks."); Gary B. Gertler, Brain Birth: A Proposal for Defining When a Fetus is Entitled to Human Life Status, 59 S. CAL. L. REV. 1061 (1986) (student author); Jones, supra, at 177; note 110 infra.

109. Roe v. Wade, 410 U.S. 113, 163 (1973) (emphasis added). 
a certain point in development, a fetus could not conceivably be said to possess such capacities. States undoubtedly have a certain latitude to determine for themselves when human life begins, but (at least in a constitutional context) their determination must be based on some plausible conception of distinctly human being. A strong candidate for the earliest possible moment satisfying this condition is viability (as we have understood the term), when the fetus's brain develops important attributes of the capacity for distinctly human mentality. ${ }^{110}$

Let us now turn finally to conception. Isn't conception arguably the one nonarbitrary point a state might choose as the advent of personhood? Doesn't a link between conception and life's beginning supply an alternative conception of personhood, "thinner" than viability but no less defensible?

When we consider the proposition that life begins at conception, we must carefully distinguish between the grounds an individual might entertain in

110. See text accompanying note 108 supra. Some advocates of "brain birth" have proposed drawing a line at 8 weeks, when the brain may first begin to emit electrical activity, see, eg., Joseph W. Dellapenna, Nor Piety Nor Wit: The Supreme Court on Abortion, 6 Colum. HUM. RTs. L. Rev. 379, 408 (1974-1975); Goldenring, supra note 97, at 199, or at 10 weeks, when "the connections between nerve cells first appear." See N.Y. Times, (Nov. 8, 1990), at A28, col. 1 (summarizing proposal made by philosopher Hans-Martin Sass). If, however, "brain birth" is to serve as the advent of personhood, these suggestions must be rejected.

First, mere electrical activity cannot signify personhood. One might as well say that a transistor radio was an independent life entitled to respect as a person. Until at least week 22, "[t]he electrical activity [in the fetal cerebral cortex] is random, irregular, unresponsive and dissociated." Cherry Thompson, Cortical Activity in Behaviourial Development, in BRAIN AND BEHAVIouRAL DeVELopMENT 131, 136 (J. Dickerson \& H. McGurk eds. 1982). As noted earlier, minimally organized cortical activity does not emerge until weeks 20 to 22 at the earliest. See note 108 supra.

Indeed, "the semblance of an adult [EEG] pattern" does not appear until at least week 32. Jones, supra note 108, at 177 . At that time the brain wave amplitudes "drop significantly to within the range seen in children and adults," Thompson, supra, at 139, and the pattern of momentary electrical bursts followed by periods of complete cortical inactivity gradually evolves into continuous, organized brain waves. See Charlotte M. Anderson, Fernando Torres \& Angelina Faoro, The EEG of the Early Premature, 60 EleCtROENCEPHALOGRAPHY \& CliNICAL NEUROPHYSIOLOGY 95, 97 (1985); Jones, supra note 108, at 177. Thus if EEG readings alone were the measure, human life should be deemed to begin at the end not of the eighth week, but of the eighth month of pregnancy. See Jones, supra note 108, at 177 (32 to 36 weeks).

Similarly, to focus on the initial appearance of interneural connections at eight or ten weetss misapprehends the fundamentals of brain development. Although a fer synapses in the cortical region may appear quite early in gestation, until at least week 19 such "synapses are present above and below the cortical plate, but never within it." Mark E. Molliver, Ivica Kostovic \& Hendrik Van Der Loos, The Development of Synapses in Cerebral Cortex of the Human Fetus, 50 Brain REs. 403, 404 (1973) (original emphasis); accord Herschkowitz, supra note 108, at 10. From their initial embryonic appearance to week 20, the cortical neurons merely develop synaptic "targets" for intra- and extra-cortical connection. Anand \& Hickey, supra note 108, at 1322 (emphasis added). At the same time, the critical fibers to which these neurons will be joined migrate to the cortical region, but "then 'wait' just below the neocortex until migration and dendritic arborization of cortical neurons are complete and finally establish synaptic connections between 20 and 24 weeks of gestation." Id. (emphasis added).

Thus, if the constitutional task is not to determine when a fetus must or should be considered a person, but solely to identify the earliest time at which a fetus could possibly be said to have attained a minimal capacity for distinctively human life, surely that condition can be met no earlier than weeks 20 to 24, when necessary structural maturation and organized electrical activity first emerge in the cerebral cortex. Cf. J. Korein, Ontogenesis of the Fetal Nervous System: The Onset of Brain Life, 22 Transplantation Proc. 982, 983 (1990) (concluding, on similar grounds, that "as a lower limit, brain life can not begin earlier than the twentieth week") (emphasis in original). 
support of his belief and the grounds a state may advance in support of its legislation. If the state were permitted to rely on the claim that God infuses a human soul into every fertilized egg, our analysis would change dramatically. An "ensoulment" claim would present a powerful, indeed essentially unanswerable, basis for states to choose conception as the moment of personhood. But religious tenets cannot be relied upon in this context any more than in others, and hence they are not to be allowed into our inquiry. ${ }^{111}$

A case, however, can be made for conception without relying on religion. Fertilization ${ }^{112}$ may be said to represent the moment of genetic completion, at which point "the entire constitution of the man is clearly, unequivocally spelled-out, including arms, legs, nervous systems and the like."113 Moreover, because the development of this genetically complete zygote is a gradual, incremental process, "there is no nonarbitrary line separating a fetus from a child."114

These arguments, although standard in the right-to-life literature, ${ }^{115}$ are virtually unintelligible. First, to link personhood to genetic completeness is untenable. Every cell in our bodies is genetically complete; every nucleus in every cell spells out the same information about the "entire constitution of the person." Quite plainly, carrying all the necessary genetic information about an individual human being cannot be equivalent to being a human being.

The argument based on the gradualness of gestation fares no better. It may be the case that no nonarbitrary line can be drawn in our ontogeny distinguishing between a mere aggregation of cells and a human being entitled to treatment as a person. But that does not make it correct-nor even plausible - to conclude that the thing at one end of the spectrum is the thing at the other. No nonarbitrary line separates the hues of green and red. Shall we conclude that green is red? That night is day?

But a zygote differs from all the other cells in someone's body, it might be said, and it differs from a color or time of day. The zygote develops into a whole human being. Might this potential for development be the decisive factor? The answer is no. An unfertilized ovum also has the potential to develop into a whole human being, but that does not make it a person. If the response is that potential development plus genetic completion equals personhood, the argument still fails. Nucleic transplantation technology (along with other cloning processes) gives to non-zygotic cells the potential for such

111. See text accompanying notes 76-78 supra.

112. Conception is not necessarily synonymous with fertilization. In fact, the American Medical Association defines conception as complete only when the fertilized ovum implants itself in the moman's uterus. See ObsteTric-Gynecologic Terminology 299, 327 (E. Hughes ed. 1972). Inasmuch, however, as states seeking to ban abortion would presumably define conception as fertilization, we shall so construe the term here.

113. Davis v. Davis, 15 Fam. L. Rep. (BNA) 2097 (Tenn. Ct. App. Sept. 21, 1989).

114. Thornburgh v. American College of Obstetricians and Gynecologists, 476 U.S. 747, 792 (1986) (White, J., dissenting).

115. See, e.g., Olsen, supra note 73 , at 127-28 (discussing well-known antiabortion pamphlet written by Dr. John Willke of the National Right to Life Committee). 
development; ${ }^{116}$ are we then obliged to look upon every cell or nucleus as a person? ${ }^{117}$

There is in addition a more fundamental problem with attempting to equate personhood with the potential for development into a "whole human being." To define "person" as that which has the potential to become a person renders "personhood" itself an empty or circular concept. In this view of fetal status, personhood (or human life) denotes no attributes (mental or physical) that distinguish independent beingness in general or human beingness in particular, but only the potential a thing has for developing certain attributes it does not yet possess. A status quite different from personhood is really at issue here. Genetic completion and the capacity for development are the defining characteristics of the seed, not the thing itself. An acorn is not an oak tree. To insist that personhood be understood as the attainment of a certain level of human development, rather than as the potential for such development, is ultimately to insist that a person must be distinguished from the biological material of which he is made.

It may be said, however, that in my discussion of viability I already tacitly invoked potentiality as the defining feature of personhood. I spoke then of mental capacities: Isn't the word "capacity" synonymous with potentiality? After all, one might argue, the viable fetus cannot reason, speak, or have moral or spiritual experiences; nor can a newborn baby. Didn't I implicitly rely on the fetus's capacity to develop higher mental faculties, rather than a present ability to exercise them?

Again, the answer is no. First, a "capacity" (as I have used the term) is not the same as a potential to develop a certain ability. A sleeping adult possesses his full complement of intellectual capacities, even if he is not currently exercising them. This is the sense of capacity-indicating the attainment of a certain level of development, not the potential for further development-to which my earlier discussion referred.

To be sure, the nature of a fetus's mental capacity is uncertain. Scientists do not purport to know whether a fetus of any age is capable of thought, apperception, or other forms of mental experience.118 But as discussed above, that was part of our reason for identifying the stage at which the cerebral cortex attains minimal structural and functional maturity as the

116. See, e.g., Mario R. Capecchi, Altering the Genome by Homologous Recombination, 244 SCIENCE 1288 (June 16, 1989) (discussing cloning of mice from embryo stem cells and certain possible applications of the process for humans).

117. Drawing the line at fertilization involves other difficulties as well, which have frequently been pointed out. To say that human life begins at conception means that more than half of all persons lose their lives before they are a week old (due to the failure of the embryo to implant itself in the uterus). It also fails to square neatly with the possibility of twinning or fusing of embryos as much as two weeks later and overemphasizes the degree to which an individual's genes "spell out" his "arms, legs, nervous system and the like." See, e.g., L. TRIBE, supra note 6, at 117-18, 123-24; Dellapenna, supra note 110 , at 406.

118. See Elizabeth Hall, When Does Life Begin? An Embryologist Looks at the Abortion Debate, PsychologX TODAY, Sept. 1989, at 42 (interview with Clifford Grobstein, professor emeritus of biological science and public policy at the University of California, San Diego, discussing the difficulty of determining when the fetus experiences psychic individuality). 
earliest possible time when the fetus may conceivably be said to attain the capacity for distinctly human mentality. ${ }^{119}$

It would be possible to end the inquiry here. The argument would then be as follows. A prohibition of abortion must rest on a conception of personhood-actual, not merely potential, personhood-defensible from a nonreligious, normative perspective. Even in the thinnest possible such conception, personhood can probably be deemed to begin no earlier than viability. At the very minimum, such a conception must look to some developmental factors that cannot plausibly be said to exist in a blastocyst.

There is, however, an additional set of considerations we have so far left out. The proposition that life begins at conception has a very particular ramification: If accepted, it would permit a state to block abortion altogether. The usual assumption, which we have implicitly adopted, is that this consequence of the proposition is irrelevant to its defensibility. I suggest now that this assumption is wrong.

\section{The Constitutional Consequences}

The fetus's personhood is usually understood to present a question logically independent of, prior to, and indeed controlling of one's conclusions about the scope of the woman's right to privacy. On this view, the fact of the fetus's personhood, once it is determined, supersedes and renders irrelevant the values of privacy.

In challenging this understanding, I do not question the conclusion that a state could override a woman's privacy rights if it were able to determine in advance that the fetus was a person. The point is that the state cannot make this determination "in advance." And if personhood cannot be determined in advance, then the consequences do not "follow." They precede.

As discussed above, personhood is not a fact or a thing but a status that, like adulthood, properly depends not only on biological developments, but also on the normative context in which the status is situated. ${ }^{120}$ In deciding the age of adulthood for purposes of drinking or criminal liability, we are certainly entitled to consider the interests of other parties. The same is true of personhood. This means the consequences of determining the fetus to be a person at some particular point may appropriately be regarded as ingredients of the determination itself. To be sure, there may be contexts where a fetus's personhood is legally relevant and where the state has relatively unfettered discretion to consider or to ignore the interests of other parties in making its determination. When, however, the fetus's personhood implicates constitutional rights, the state's determination must take into account the constitutional consequences.

Consider the "exigent circumstances" doctrine in fourth amendment

119. See notes 108,110 supra.

120. See text accompanying note $43-47$ supra. 
law"121 or the "clear and present danger" test in first amendment jurisprudence. ${ }^{122}$ As with personhood in the abortion context, a finding of exigent circumstances or of a clear and present danger authorizes a state to qualify a constitutional right. Can there be any doubt that discerning the limits of these two concepts must include a consideration of the relevant constitutional values? One could approach questions of "exigency" or "danger" as if they were purely factual, as if they had to be resolved prior to and independent of the remainder of the fourth or first amendment analysis. So long as the circumstances involved no plausible dispute, this approach would appear satisfactory. But as soon as the circumstances raised any appreciable controversy, determining whether the necessary "exigency" or "danger" existed would plainly demand that we take into account the principles and purposes of the fourth or first amendment itself. ${ }^{123}$

Specifically, when taking these constitutional considerations "into account," we must be observant of the degree to which a state's proposed determination, if accepted, would cut into the core of the right at issue. To be sustained, a state's claim of compelling governmental interests must appropriately delineate the outer limit of a constitutional right. It cannot be permitted to eviscerate the right altogether.

Would we allow a state to determine that "exigent circumstances" exist whenever a crime has been committed and the perpetrator remains at large? Or that a "clear and present danger" comes into being as soon as persons assemble to demonstrate for a controversial cause? In rejecting these positions, we could not plausibly say that these circumstances pose no threat to public safety. Rather, we would straightforwardly say that this kind or degree of threat cannot be sufficient, for the simple reason that the result of such a rule would eviscerate the constitutional right at stake. It would eliminate altogether the constitutional liberty whose outer boundary was supposedly being drawn.

The same analysis invalidates the proposition that life begins at conception. As discussed earlier, the right at issue here is the freedom to decide whether and when to bear children. This is the right recognized in the contraception cases ${ }^{124}$-and indeed in cases decided even before the right to privacy had a name. ${ }^{125}$ Precisely because it would render abortion com-

121. See, e.g., Steagald v. United States, 451 U.S. 204 (1981); Payton v. New York, 445 U.S. 573 (1980).

122. See note 31 supra.

123. See, e.g., Payton, 445 U.S. at $587-90$ (fourth amendment); Whitney v. California, 274 U.S. 357, 374 (1927) (Brandeis, J., concurring) (first amendment); PAUL FrEUND, ON UNDERSTANDING THE SUPREME COURT 27-28 (1949) (first amendment).

124. See text accompanying notes 17-22 supra.

125. See, e.g., Skinner v. Oklahoma ex rel. Williamson, 316 U.S. 535 (1942) (invalidating a statute providing for sterilization of persons convicted of two or more "felonies involving moral turpitude" and stating that the right to reproduce is "one of the basic civil rights of man," id. at 541). The right to marry, which has roots extending still further in our constitutional law, see, eg., Meyer v. Nebraska, 262 U.S. 390, 399 (1923), should also be recognized as encompassing or even resting on the right to choose whether and with whom to bear children. Cf. Loving v. Virginia, 388 U.S. 1 (1967) (invalidating miscegenation statute). 
pletely unavailable, a state determination that life begins at conception would not place an outer limit on this right; it would eviscerate the right at its core.

Only if a state draws its line of personhood sufficiently late in gestation for women to have time to discover their pregnancy and obtain an abortion (if they so choose), can women meaningfully retain the right to decide whether and when to have children.

But an obvious objection will be made here. Deeming life to begin at conception may "eviscerate" women's freedom to have an abortion, but in what sense does it "eviscerate" their right to decide whether and when to have children? After all, it will be said, women under Eisenstadt are guaranteed the availability of contraception, and more than that, they can always choose to avoid sexual intercourse altogether. Hence, even if abortion were completely prohibited, women would clearly remain free to make their own reproductive decisions.

This objection is unavailing. ${ }^{126}$ First, contraception is no guarantee against pregnancy. Studies indicate that over half of the women who currently obtain abortions do use some form of contraception. ${ }^{127}$ Even in the strongest of cases-assuming women to be fully informed and vigilantly using one of the more effective contraceptive devices-the odds of pregnancy would by no means be negligible. ${ }^{128}$ In actual practice, moreover, effectiveness rates are not nearly so high as they are claimed to be, which means that the chances of pregnancy despite contraception are quite substantial even over the course of a single year. ${ }^{129}$

Equally important, the fact is that a great deal of unwanted pregnancies occur among the women youngest, poorest, least informed, and therefore least able to employ contraception effectively. ${ }^{130}$ Despite the availability of contraception, hundreds of thousands of unwanted pregnancies occur each year, and in every case a blanket prohibition of abortion would mandate compulsory childbearing. When abortion is prohibited, no woman is guar-

126. In saying so, I do not rely on an argument based on the possibility of rape because the reply could be that an exception should be made in the event of pregnancies resulting from rape. Nor do I rely on other forms of "forced" intercourse, see, e.g., Olsen, supra note 73, at 125, although the entire network of pressures directing women into sex and childbearing is undoubtedly relevant here.

127. See N.Y. Times, Oct. 22, 1988, § 1, at 26, col. 1 (discussing studies from the Alan Guttmacher Institute which found that "slightly more than half the American women who choose abortion are using a contraceptive during the month in which they conceive").

128. "Even a woman who uses a contraceptive that is $95 \%$ effective has a $70 \%$ probability of pregnancy over ten years." Andrew Koppelman, Forced Labor: A Thirteenth Amendment Defense of Abortion, 84 Nw. U.L. REv. 480, 505 (1990).

129. See Betsy A. Lehman, Study: Birth Control Fails More Than Surveys Show, Boston Globe, July 13, 1989, (National/Foreign), at 3, col. 4 (discussing a study by Alan Guttmacher which found that birth control "fails more often than currently accepted statistics indicate"). See generally John A. Ross, Contraception: Short-Term vs. Long-Term Failure Rates, 21 Fam. Plan. Persp. 275 (1989).

130. See Lehman, supra note 129 ("[W]omen who are poor, unmarried, young, black or Hispanic ... [are] more likely ... than other women to use contraception inconsistently, resulting in unwanted pregnancies ...."). 
anteed the right to decide whether or when to have children, and a large number of women will in fact have childbearing forced upon them against their will.

But what of abstinence? Every woman remains perfectly free to abstain from sex altogether. Given that fundamental freedom, how can even the strictest antiabortion law be said to "compel" childbearing?

This argument, suggested by Solicitor General Kenneth Starr in a recent amicus brief, ${ }^{131}$ is startling in its spuriousness. To insist upon women's potential "abstinence" is to say that if women have sex, they must accept childbearing, or at least assume the risk of it. But this is the very opposite of assuring women the freedom, recognized in Griswold and Eisenstadt, to decide whether and when to bear children. It is to relegate women to the very same lack of freedom under which they labored before Griswold. A state's reliance on contraception as a guarantee of women's privacy right is inadequate; a state's reliance on abstinence renders the right meaningless.

All this might be granted, but our conclusion may still seem too simple. "Everything you have said," one might object, "simply proves that the right to privacy would be strengthened by a right of abortion. But no one disputes that. The question here is one of balancing the right of privacy against the fetus's right to life. To say that the right of privacy generally weighs against regulation of abortion simply restates the problem. It tells us nothing about where to draw the line. To the contrary, if your argument was accepted, we would have to conclude that the state could not prohibit abortion at any time during a woman's pregnancy."

Not at all. If, for example, right-to-life advocates believed that life commences upon quickening and wanted to overturn $R o e$ on that ground, then the values protected by privacy might not tip the balance one way or the other. Provided that women who become pregnant are allowed a reasonable length of time to discover their pregnancy and to obtain an abortion (should they so choose), women meaningfully retain the constitutional freedom to make their own childbearing decisions. When abortion is prohibited altogether, they do not. I am not saying that a state cannot determine fetal personhood to commence upon conception because the right to privacy "weighs against" it; I am saying that the state cannot do so because that would eviscerate the right at its core.

"But let's be serious," someone may say. "The availability of contraception and abstinence may not guarantee a woman's freedom to decide whether and when to have a children, but surely it goes a long way in that direction. If a large number of women remain ill-informed about contraceptives or simply fail to use them (either properly or at all), that is not the state's responsibility. At the very least, contraception sufficiently vindicates

131. See Dellinger \& Sperling, supra note 29, at $97 \mathrm{n} .51$ (discussing Brief for the United States as Amicus Curiae Supporting Respondents, Hodgson v. Minnesota, 110 S. Ct. 2926 (1990) (No. 881125)). 
the woman's liberty interest to render a compelling state interest unnecessary in the context of abortion laws."

This objection raises two important points. First, so long as women are permitted a fairly high degree of potential control over their reproductive decisions, why isn't their constitutional right satisfied? Second, even if not fully satisfied, perhaps the right receives sufficient protection from the availability of contraception to allow state regulation of abortion on the basis of something less than a compelling interest. If so, abortion might be prohibited merely because of our "uncertainty" about the advent of human life, or merely to "foster respect for human life"-without, in either case, deeming the fetus an actual human life.

To answer these questions, let us imagine a statute imposing a quarantine upon any person who contracts the flu. The quarantine consists of a year's internment in a state institution. We ask the state what compelling interest justifies this enormous deprivation of liberty. The state's counsel replies, "Didn't you hear? There's a new pill available that prevents flu with 99.9\% effectiveness, and it's available at any drugstore. Thus, our statute can adversely affect only those who fail to take this pill or those few who catch the disease notwithstanding."

Supposing those facts are true, can they make any difference? Can they possibly excuse the state from the necessity of demonstrating a compelling interest?

"But the two cases are not alike," our original interlocutor will protest. "The Eisenstadt right is a right to a certain degree of control over one's reproductive life. Access to contraception satisfies and exhausts the right. Even if pregnancy ensues, there is simply no constitutional right left for the state to violate. The situation is entirely different in the case of a right to physical liberty. This right not to be confined is in no way satisfied by taking a flu pill."

This rejoinder, assuming it even intelligible, is patently incorrect. Privacy is also a right not to be confined: a right not to be confined in a life of the state's choosing; a right not to have the future course of one's life dictated by the state. ${ }^{132}$ To be forced by state law to bear a child constitutes the exemplary case of deprivation of this right. Contraception does not "satisfy" or "exhaust" the right of privacy. Like the flu pill, it acts as a preventative, the failure of which cannot permit the state to effect a massive intrusion into one's liberty.

Moreover, the fact that the abortion laws operate in the field of sexual desire is itself germane to the need for strict scrutiny. State direction of individuals' lives is particularly dangerous when effected by laws that operate on or take advantage of elemental human desires. The formal legal freedom to refrain from acting on such desires makes little difference. Indeed, the preservation of this sort of formal freedom is a characteristic feature of

132. See Rubenfeld, supra note 71, at 787; see also L. TRIBE, supra note 6, at 102-03; Estrich \& Sullivan, supra note 56, at 130. 
the laws invalidated by the right to privacy. ${ }^{133}$ Despite the freedom to abstain, men and women always have engaged and always will engage in sexual intercourse, often at the risk of severe consequences; despite today's availability of contraceptives, women will become pregnant. A state that flatly prohibits abortion is fully chargeable with compelling women to bear children.

But perhaps the case of quarantine laws raises a new problem. "You say that states may not define their compelling interests in such a way as to deprive persons completely of a constitutional right. But quarantine laws prove that states may do so. If a quarantine were genuinely necessitated by a compelling interest-if, let's say, it was the only way to prevent a plaguethen presumably we would permit the state to intern carriers of the disease. ${ }^{134}$ Therefore, I see no reason why the state may not draw its personhood line at conception, even if this would deprive women of their privacy right."

Certainly government may abridge constitutional rights when necessary to protect a compelling state interest; that is what it means to have a compelling state interest doctrine. ${ }^{135}$ The point, rather, is that states may not draw their compelling interest lines so broadly as to eliminate or eviscerate a constitutional right altogether. Thus, in the case of a state's declaration that a clear and present danger exists whenever people protest the current administration's policies, the right at issue would not be limited, but destroyed. In an important sense, there would be no meaningful right of free speech if political dissent were forbidden. Similarly, for all the reasons suggested above, there would be no meaningful right to decide whether and when to have children if abortion were forbidden.

Our interlocutor gets one last opportunity. "But an antiabortion law no more eviscerates the right to privacy than the quarantine law eviscerates the right to liberty. The former applies its restrictions only to women who get pregnant, just as the latter applies only to those who get the disease. Everyone else remains perfectly free. If your argument about abortion was right, then the state could never quarantine anybody."

Two responses are available to us here. First, we might point out that the condition of carrying a deadly contagion differs significantly in its relation to the right of liberty from the condition of being pregnant in relation to the right not to bear children. Saying that everyone but plague carriers remains unincarcerated can mean a great deal; saying that everyone but pregnant women remains free not to bear children is absurd. To use the latter

133. For example, miscegenation laws of the sort struck down in Loving v. Virginia, 388 U.S. 1 (1967), leave individuals formally free not to marry or procreate at all, but in substance, channel persons' lives into the institutions of intraracial marriage and procreation. Similarly, a law limiting occupancy of dwellings to members of an immediate family, see Moore v. City of E. Cleveland, 431 U.S. 494 (1977), exerts a powerful standardizing force on lives even though persons always remain free to live alone. See Rubenfeld, supra note 71, at 784, 792.

134. Here our objector might cite Korematsu v. United States, 323 U.S. 214 (1944) (upholding an internment despite strict scrutiny).

135. The doctrine could in principle be challenged, but $I$ have made no such argument here. 
proposition in defense of abortion laws is like defending a sedition act on the ground that it applies only to dissenters: "Everyone else" remains perfectly free to speak his mind. Sedition and antiabortion laws do not stake out an outer boundary of a recognized constitutional right; they traverse the right's very core.

On the other hand, we might accept our interlocutor's invitation to treat the antiabortion and quarantine contexts as analogous. Today especially it is easy to imagine a quarantine law that, while supposedly protecting us from a plague, nonetheless raises the most serious constitutional questions. In both contexts, the principle would surely hold that states cannot define their compelling interests so broadly as to obliterate constitutional rights.

Moreover, we can imagine what sort of showing the state would have to make to convince us that a disease compellingly mandated quarantine. But what sort of showing can the state make to convince us that a newly conceived embryo is a person? Could any showing be "convincing" in the same sense? Our earlier discussions may not have refuted the proposition that personhood begins at conception, but surely that proposition fared no better-and indeed rather worse-than arguments favoring later gestational events.

But this very uncertainty might be said to be the chief reason that the judiciary ought to defer to state determinations of fetal personhood. Doesn't such uncertainty cut precisely against a single constitutional rule? We have seen this argument before. If nothing said already has persuaded the reader of its inapplicability, consider a final illustration. According to the understanding of personhood we have tried to elucidate here, the dispositive analogy would be to a law determining the advent of adulthood in a context where that determination implicated other individuals' constitutional rights. For lack of a better example, take the purchase and sale of pornographic but nonobscene photographs, generally protected by the first amendment. ${ }^{136}$ Let us assume, however, that when the subjects photographed are under a certain age, the distribution of such materials may be barred based upon the state's compelling interest in protecting the morals or welfare of minors. ${ }^{137}$

Now suppose that a state, for purposes of pornographic photography, deems adulthood to begin at forty or even sixty-five. When a buyer brings a first amendment challenge, the state moves to dismiss, insisting that neither the Constitution nor the judiciary can have anything to say about the commencement of adulthood. Specifically, the state argues that there can be no constitutional rule in the face of society's uncertainty about the age at which true maturity is attained. Surely we would reply that the state's discretion in determining the age of majority, broad as it may be in many contexts, is necessarily constrained when constitutional rights are at stake. When the

136. See, e.g., American Booksellers Ass'n v. Hudnut, 771 F.2d 323 (7th Cir. 1985), aff'd, 475 U.S. 1001 (1986).

137. See New York v. Ferber, 458 U.S. 747, 757 (1982); see also Sable Communications, Inc. v. FCC, 109 S. Ct. 2829, 2839 (1989) (recognizing a compelling state interest in protecting minors from "indecent" speech). 
determination would effectively destroy or eviscerate a constitutional right, the state has plainly exceeded its constitutional authority.

In the absence of a far more persuasive showing than can be made, a state cannot for abortion purposes deem life to begin upon conception. To insist that a state make a persuasive case is ultimately what it means to demand compelling grounds for the limitation of constitutional rights. Even if, apart from the constitutional considerations, conception was "just as good" a point to locate personhood as any other gestational event, nonetheless, given the constitutional consequences, "just as good" cannot be good enough.

This, in the end, was the holding of Roe. In light of the state's inability to demonstrate that a fetus is a person, the Court did "not agree that, by adopting one theory of life, [a state] may override the rights of pregnant women at stake." 138 Too strictly construed, this formulation would be incorrect. A state may override a woman's privacy rights (indeed may only override them) by "adopting [a] theory of life"-that is, by determining a point at which to recognize the fetus as an independent human being. The Court's essential holding, however, was and remains valid: A state may not completely eviscerate the women's privacy rights by adopting a theory of life that bars abortion altogether.

\section{Conclusion}

We can no longer look at prenatal life through Roe's colored glasses. If and when the Court confronts the insufficiency of "potential life" as a basis for prohibiting abortion, it will have three coherent options. It can, first of all, repudiate the right of privacy. This path will not be an easy one, even for the conservative justices. The Court cannot reject privacy merely on the ground that the right is not textually specified, unless the Court is prepared to do away at the same time with a host of other well-established constitutional guarantees. ${ }^{139}$ Nor can the Court on any ground abolish the right to privacy without allowing the states unchecked power to dictate whether we can use contraceptives, whether or whom we will marry, ${ }^{140}$ whether we can obtain a divorce, ${ }^{141}$ which relatives we can have in our households, ${ }^{142}$ which schools we will send our children to, ${ }^{143}$ and, I should think, even what profession we can pursue. ${ }^{144}$

Second, assuming the Court preserves the right to privacy, it can announce as a new constitutional standard that states may deem the fetus a

138. Roe v. Wade, 410 U.S. 113,162 (1973).

139. For example, the freedom of association, the immunity from criminal conviction except upon proof beyond a reasonable doubt, the rights to vote and to travel, and every Bill of Rights guarantee as applied against the states. See, e.g., Estrich \& Sullivan, supra note 56, at 125 n.12.

140. See, e.g., Zablocki v. Redhail, 434 U.S. 374 (1978); Loving v. Virginia, 388 U.S. 1 (1967).

141. See, e.g., Boddie v. Connecticut, 401 U.S. 371 (1971).

142. See, e.g., Moore v. City of E. Cleveland, 431 U.S. 494 (1977).

143. See, e.g., Pierce v. Society of Sisters, 268 U.S. 510 (1925).

144. See Rubenfeld, supra note 71, at 803-04. 
person at any point in pregnancy they choose, so long as this point affords women a reasonable length of time in which to discover their pregnancy and obtain an abortion. This would be the minimally defensible constitutional holding if, as I have suggested, the right of privacy precludes state determinations of fetal personhood that would prohibit abortion altogether. This standard would, however, have obvious disadvantages. It would lack definiteness, invite additional litigation, result in differing state rules, and so forth. On the other hand, the Court would be going no further than it had to go and would be allowing antiabortion states as much leeway in prohibiting abortion as the Constitution could tolerate. ${ }^{145}$

Finally, the Court can forthrightly decide when states may earliest deem the fetus to be a person. This alternative would face accusations of arbitrariness and of "judicial legislation," 146 but, as we have repeatedly observed, it is ultimately up to the federal judiciary, not the state legislatures, to determine the existence of those state interests that allow the abridgment of constitutional rights. If the Court takes this route, the decisive gestational moment ought to satisfy two conditions: It must be late enough in pregnancy to assure women a reasonable time to discover their pregnancy and obtain an abortion, and it should reflect the most minimal (nonreligious) conception of personhood upon which states could plausibly rely.

In this analysis, viability will again suggest itself. The reason for Roe's success (such as it was) is that, despite its vocabulary of potential life, the Court in all essential respects made a determination about when the states could deem the fetus a person. Viability never made sense as the point at which the state interest in potential human life becomes compelling. Its appeal lies in its demarcation of a stage at which the fetus, having become "capable of meaningful life outside the mother's womb," 147 may be regarded as a distinct life-in-being with interests of its own-as, in short, a person. Viability, in this sense, is by no means a unique or flawless solution to the problem of locating such a stage in the fetus's development. It is only a good solution. Under the circumstances, however, that is an excellent recommendation.

145. Ironically, however, the ability of such states to prohibit abortion at an early stage in pregnancy could depend on their willingness to make abortion more easily available, say through public funding of pregnancy tests and abortion facilities.

146. E.g., Roe v. Wade, 410 U.S. 113, 174 (1973) (Rehnquist, J., dissenting).

147. Id. at 163. 
HeinOnline -- 43 Stan. L. Rev. 636 1990-1991 